\title{
Arbuscular mycorrhiza symbiosis in viticulture: a review
}

\author{
Sophie Trouvelot ${ }^{1} \cdot$ Laurent Bonneau $^{1} \cdot$ Dirk Redecker $^{1} \cdot$ Diederik van Tuinen $^{2}$. \\ Marielle Adrian ${ }^{1}$ - Daniel Wipf ${ }^{1}$
}

\begin{abstract}
Viticulture is a major worldwide economic sector with a vine area of 7.52 million ha, wine production of $288 \mathrm{Mhl}$, and wine exports of 26 billion euros. Nevertheless, viticulture has to adapt to new challenges of pest management, such as pesticide reduction, and climate change, such as increasing droughts. Viticulture adaptation can benefit from arbuscular mycorrhiza, a plant-fungus symbiosis. Here, we review the ecosystemic services of arbuscular mycorrhiza for grapevine production. The major points are the following: (1) arbuscular mycorrhiza fungi increase grapevine growth and nutrition by a better access to soil nutrients and by activating the regulation of plant transport proteins for phosphorus $(\mathrm{P})$, nitrogen $(\mathrm{N})$, and other elements. (2) Arbuscular mycorrhiza fungi increase the tolerance to abiotic stresses such as water stress, soil salinity, iron chlorosis, and heavy metal toxicity. (3) Arbuscular mycorrhiza fungi protect against biotic stresses such as root diseases. (4) Arbuscular mycorrhiza fungi produce glycoproteins and a dense hyphal network that increases soil stability and save soil nutrients up to $14 \%$ of the grape production income. (5) P fertilisation reduces mycorhization. (6) Using herbaceous plants as cover crops favors arbuscular mycorrhiza fungi.
\end{abstract}

Sophie Trouvelot and Laurent Bonneau contributed equally to the work.

Daniel Wipf

daniel.wipf@dijon.inra.fr

1 Université de Bourgogne, UMR1347 Agroécologie, BP 86510, F-21000 Dijon, France

2 INRA, UMR1347 Agroécologie, BP 86510, F-21000 Dijon, France
Keywords Arbuscular mycorrhiza · Grapevine · Vineyard

Contents

1. Introduction

2. Potential importance of mycorrhizal diversity

3. Enhancement of growth and nutrition

3.1 AM symbiosis reduce the need of fertilizers

3.2 AM symbiosis enhance $\mathrm{P}$ uptake

3.3 AM symbiosis enhance $\mathrm{N}$ uptake

3.4 Impact of AM symbiosis on the uptake of other nutrients

3.5 How does grapevine cope with AM symbiosis carbon cost?

4. Increase of tolerance to abiotic stresses

4.1 AM symbiosis alleviate grapevine water stress

4.2 AM symbiosis help grapevine to cope with calcareous soil and iron deficiency

4.3 AM symbiosis increase grapevine tolerance to soil salinity

4.4 AM symbiosis increase grapevine tolerance to heavy metals

5. Protection against biotic stresses

6. Increase of soil stability

7. Impact of vineyard agricultural practices on grapevine mycorrhization

7.1 Impact of soil management practices

7.2 Impact of high fertilizer inputs

7.3 Impact of weed / cover crops

7.4 Impact of pest management practices

8. Conclusion

9. References 


\section{Introduction}

Grapevine is a perennial crop grown in various areas around the world. It is highly responsive to local environmental conditions and viticultural practices, hence leading to highly specific wines. This feature gradually brought about the « terroir » concept, officially defined by the International Organization of Vine and Wine (OIV) as "a concept which refers to an area in which collective knowledge of the interactions between the identifiable physical and biological environments and applied vitivinicultural practices develops, providing distinctive characteristics for the products originating from this area" (Resolution OIV/Viti 333/2010). Climate and soil characteristics associated to terroir have now been largely studied for a long time. In comparison, interest for the « microbial terroir » of vines (Gilbert et al. 2014) is recent and remains less investigated. Valero et al. (2007) and Setati et al. (2012) were among the first to study the yeast microbiome in vineyards. More recently, on the basis of the analysis of the wine-grape surface microbiome, Bokulich et al. (2014) proposed the existence of a non-random microbial terroir as a determining factor of regional variation among vines. The soil microbiome is undoubtedly also of importance but still remains less studied.

Among soil microorganisms, arbuscular mycorrhizal fungi (AMF) are able to establish symbiotic associations with vine roots (Fig. 1). Arbuscular mycorrhizal symbiosis is probably the most widespread beneficial interaction between plants and microorganisms (Smith and Read 2008; Parniske 2008). This association between plant and fungi from the Glomeromycota phylum dates back to the first appearance of land plants (about 400 million years ago) (Redecker 2000). Nowadays, the vast majority $(80 \%)$ of land plant species form AM symbiosis,

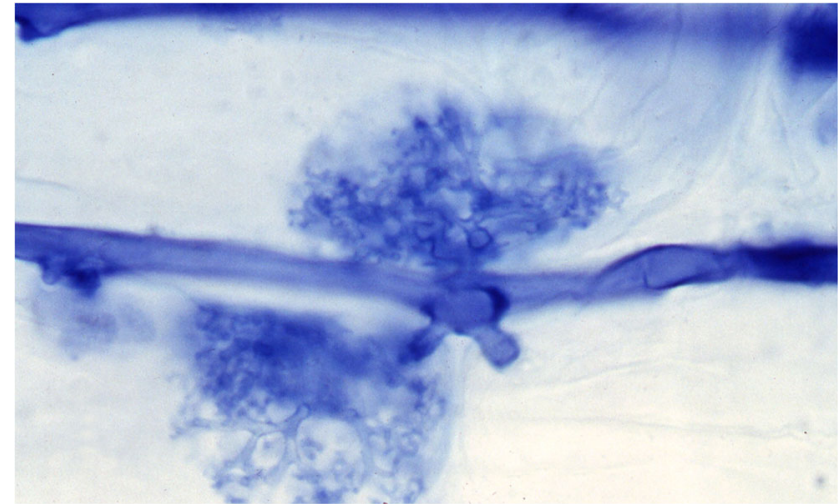

Fig. 2 Trypan blue stained root cell of Vitis vinifera, showing an arbuscule, intracellular specialized structure formed by branching of fungal hyphae that invaginate during penetration of cortical root cells. The arbuscule is the main site of reciprocal nutrient exchanges between the two partners

living in a wide range of terrestrial environments (Wang and Qiu 2006). This mutualistic interaction is based on biotrophic nutrient exchanges between the plant and the fungal partner: The host plant supplies the biotrophic partner with carbon (C) while the AMF enhances the ability of the plant to get water and nutrients from the soil (Smith and Read 2008). Nutrients are mainly transferred to the host at the biotrophic interface in cortical cells within which complex fungal structures, namely arbuscules, are developed (Fig. 2). As they constitute a direct soil-vine link, investigating their occurrence and impact in vineyard conditions will allow the assessment of their contribution to the « terroir » that is undoubtedly of particular high importance in viticulture.

This is nevertheless complex regarding the high diversity of vine material compared to other cropping/agricultural systems (rootstocks, cultivars, and clones), pedoclimatic
Fig. 1 Belowground, vine roots can form, with soil fungi, a symbiotic association (the arbuscular mycorrhiza) with mutual benefits. Fine fungal hyphae greatly increase the volume of soil explored, giving so a better access to soil nutrients and water. (Drawing by Lacaralle and OhPonyBoy)

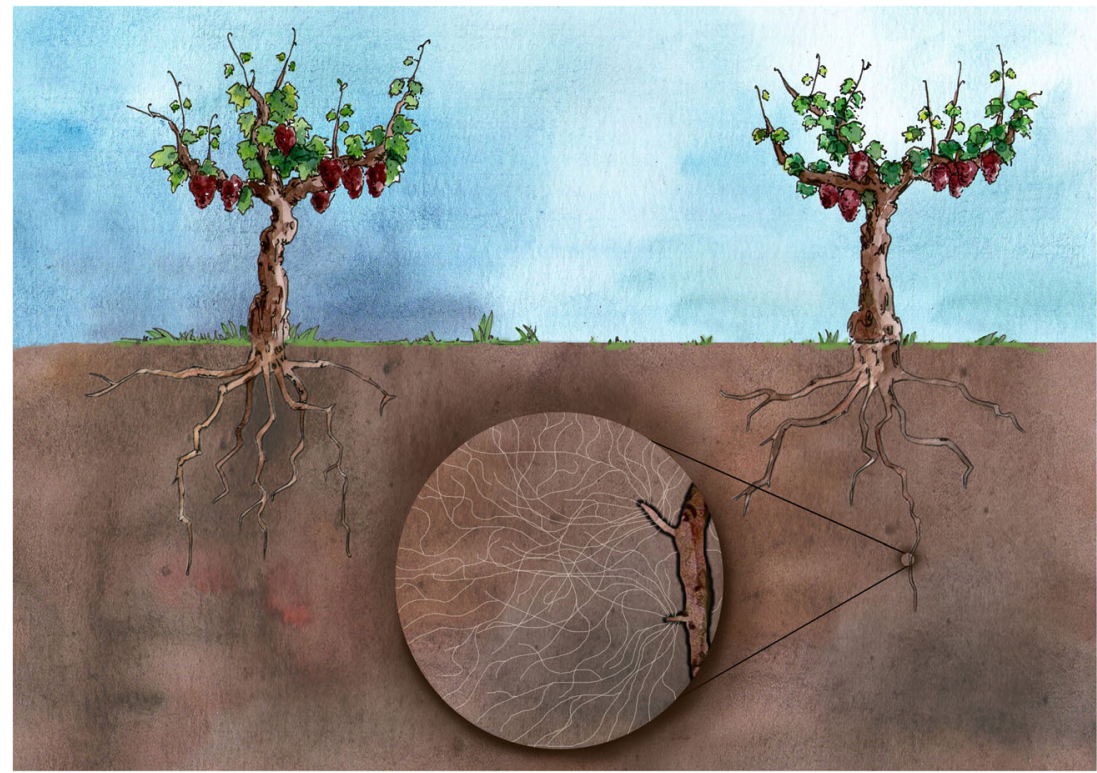


conditions, and viticultural practices. Additionally, there is increasing interest from winegrowers, technical institutes, and the scientific community for a better knowledge of the possible ecosystemic services AMF could provide with respect to adaptation to climate evolution and development towards sustainable viticulture. Obtaining an overview of the occurrence, functioning and benefits of AFM in the vineyard therefore still remain a true issue.

This paper thus presents the state-of-the-art knowledge about AMF, their impact on grapevine, and the influence of viticultural practices on these populations. It does not aim at presenting a complete review but rather highlighting the main aspects of the thematic, including recent papers.

\section{Potential importance of mycorrhizal diversity}

Biodiversity has long been recognized as one of the elements of functional ecosystems (Balvanera et al. 2006; Hector and Bagchi 2007), but most studies targeted aboveground organisms (van der Heijden et al. 1998). Recent studies show that key ecosystem processes are affected by a loss in soil biodiversity (Wagg et al. 2014) and that land usage has a great impact on it (de Vries et al. 2013). AMF are an important functional group in soil ecosystems, and a reduction of their biodiversity will impact plant functionality and more generally global ecosystems (Jeffries et al. 2003). All the fungi able to establish an arbuscular mycorrhizal symbiosis are grouped in the Glomeromycota phylum (Schüßler et al. 2001), but root colonization strategies differ among the different families. For example, fungi from the Glomerales family primarily colonize root systems starting from a hyphal fragment, while root colonization by Diversisporales starts from spores (Hart and Reader 2002a). At the family level, this implies that fungi from the Diversisporales are slower colonizers than members of the Glomerales (Hart and Reader 2002b). Differences in growth strategies between these fungi imply that soil management can greatly impact the diversity of AMF and as a consequence their ecosystemic services (Fig. 3). Indeed, in the vineyard, AMF communities are highly influenced by the soil characteristics but also to a smaller extent by the host plant development stage (Schreiner and Mihara 2009; Balestrini et al. 2010). Moreover, although AMF from grape roots mainly belong to the Glomerales group, members of the Diversisporales are mainly found in sandy vineyard soils (Balestrini et al. 2010). As a consequence, this biological functional community has to be better taken into account (Jeffries et al. 2003).

Although AMF are not host specific, their effect on plants can vary among species and isolates. When grown in the presence of heavy metals, Glomus versiforme improved mineral nutrient uptake of Sorghum bicolor and Zea mays to a greater extent than Glomus mosseae (Guo et al. 2013). On the other hand, G. mosseae was more efficient in bioprotecting tomato (Pozo et al. 1999) and petunia (Hayek et al. 2012) plants than Glomus intraradices. As discussed above, AMF develop an extensive mycelium in the soil, thereby extending the nutrientprospecting zone of the plant. The extent of the mycelium varies among species and also among isolates within a same species (Munkvold et al. 2004; Avio et al. 2006), implying that the beneficial effect of this fungal network against soil erosion or for improving plant nutrition varies depending on fungal diversity.

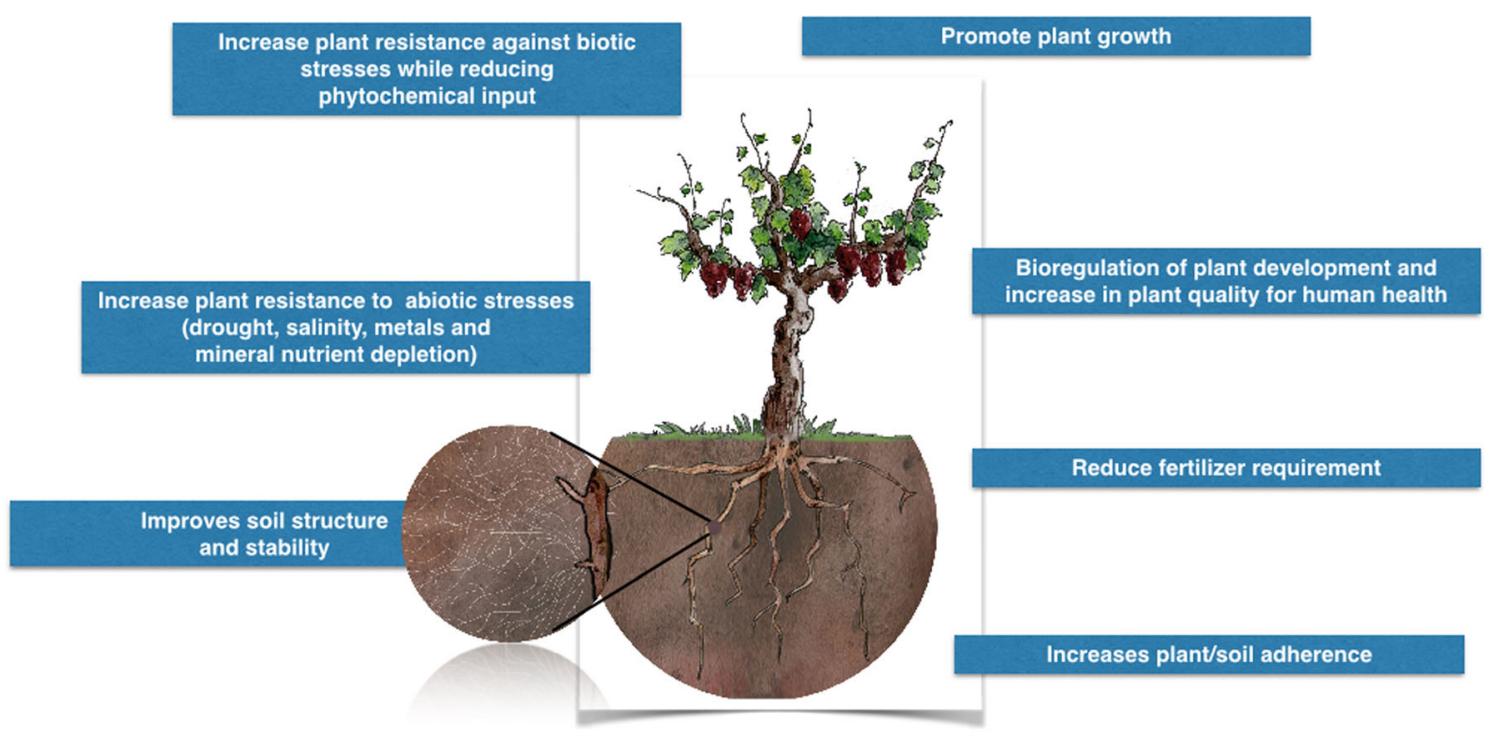

Improves soil water retention

Fig. 3 Ecosystem services provided by arbuscular mycorrhiza 
The beneficial effect on plant nutrient content has also been shown to be dependent on fungal diversity for various crops such as sweet potato (Farmer et al. 2007) or pepper plant (Gogoi and Singh 2011). When a mycorrhizal inoculum is used, the positive effect of mycorrhizal fungi on plant growth strongly depends on its composition, and a combination of mycorrhizal fungi is more effective than a monospecific inoculum (Gustafson and Casper 2005; Jansa et al. 2008; Sharma et al. 2009; Gogoi and Singh 2011). For example, in Vitis vinifera, the use of a mixed inoculum was more efficient than a monospecific inoculum regarding increases in leaf number or in leaf surface (Krishna et al. 2005). Inoculation with AMF even increased total phenolic components in leaves by up to $800 \%$ (Krishna et al. 2005).

The question as to which AMF are associated with grapevine has been addressed in several studies, initially using surveys based on spore morphology (e.g., Schubert and Cravero 1985; Oehl et al. 2005). These studies highlighted the dominance of species of the former genus Glomus s.l., now classified in genera such as Glomus s.str., Rhizophagus, Funneliformis, Claroideoglomus, and Paraglomus.

Recent studies have used DNA-based detection and identification methods to analyze AMF communities in colonized roots. Schreiner and Mihara (2009) mainly detected sequences of phylotypes assigned to the Glomeraceae family in a set of ten vineyards in Oregon (USA). Among them was only one known species, nowadays classified as Rhizophagus irregularis, as well as very few Claroideoglomeraceae and Gigasporaceae sequences. The family Acaulosporaceae was not found in roots, although species were present as spores and their ability to colonize grapevine roots was demonstrated in a separate experiment using sterilized soil. The majority of grapevine roots across vineyards were dominated by the same three or four phylotypes (out of a total of 6-11), with subtle differences across different soil types and vineyard ages. However, no seasonal effect was found. In addition, Paraglomeraceae and Archaeosporaceae were detected using primers specifically targeted to these families. Interestingly, there was a strong discrepancy between these results and the species detected in the same sites. Scutellospora calospora was the most frequently encountered species based on spores (Fig. 4), but it was rarely found in roots. Funneliformis mosseae, although abundant as spores, was not detected at all within roots.

These findings are largely in agreement with a study by Balestrini et al. (2010) conducted in two vineyards in Piedmont (Italy). Glomeraceae equally dominated the AMF communities detected by these authors in roots using DNA markers, whereas Acaulosporaceae were completely absent. Some phylotypes were in common with the Oregon study, such as certain Glomeraceae, and rare S. calospora. Communities in the two different sites differed strongly, which were attributed to the different soils. Again, spore and sequencebased approaches were in strong disagreement.

Lumini et al. (2010) used a pyrosequencing approach in vineyards in Sardinia to characterize local AMF communities. This method can be expected to deliver a much more exhaustive analysis of AMF diversity. These authors defined operational taxonomic units based on their sequences but limited their conclusions to Glomeromycotan orders. Overall, the
Fig. 4 Spores of different species of arbuscular mycorrhizal fungi (Picture by Louis Mercy)

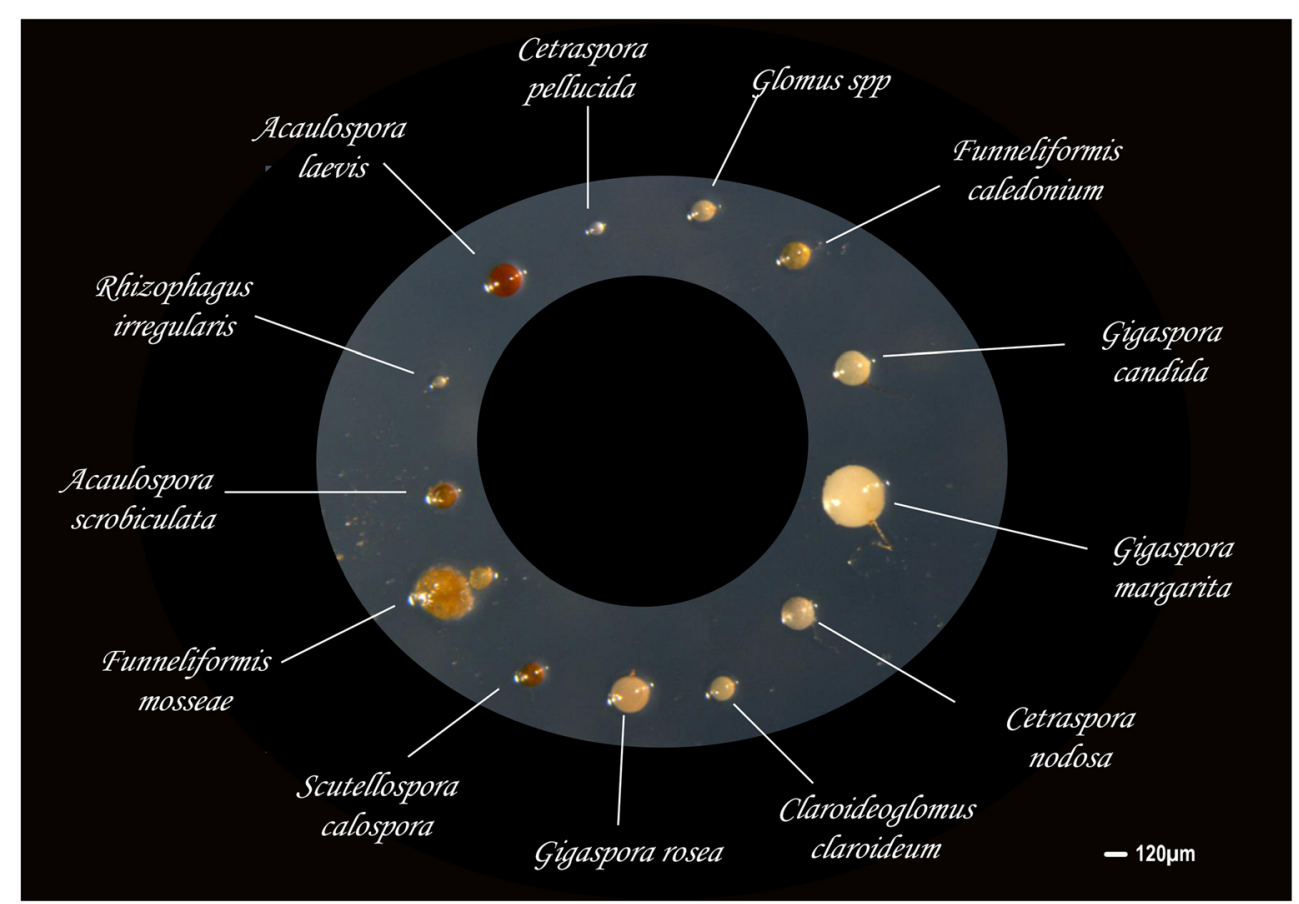


order Glomerales was again dominant. Two differently managed types of vineyards, analyzed as part of a land-use gradient, harbored slightly different levels of AMF diversity. Using a similar sequencing technology, Holland et al. (2014) addressed the question whether communities in grapevine roots were different from those detected in the accompanying interrow vegetation in vineyards in British Columbia (Canada). Although both habitats were similar in alpha diversity and qualitative composition of AMF communities, significant differences were found in terms of sequence abundance after casting aside possible effects of soil chemistry. The authors interpreted these findings as an effect of host identity and concluded that the presence of inter-row vegetation in vineyard had an effect on the overall vineyard's AMF community. However, we should keep in mind that all inter-row plants were herbaceous and thus strongly differed in root morphology and lignin content from the woody roots of vine. The taxa identified in this study belonged to the genera Rhizophagus, Funneliformis, and Claroideoglomus, together with many unidentified Glomeraceae. Notably, soil chemistry did not have a significant influence in this study.

In summary, there is currently not much conclusive evidence to set AMF communities in vineyards apart from communities in similar habitats. A dominance of Glomeraceae in colonized roots has also been demonstrated for many other ecosystems. Differing molecular marker systems and sampling efforts make it difficult to compare the different studies to obtain a general picture of the diversity of AMF communities in vineyards. Table 1 summarizes the taxonomy of the AMF species cited in this review at the time of these publications and the present consensus taxonomy. To avoid confusion, in the text, we have used the classification at the time of

Table 1 Glomeromycota taxonomic name correspondences between present and previous classification

\begin{tabular}{ll}
\hline $\begin{array}{l}\text { Arbuscular mycorrhizal fungi } \\
\text { classification at the time of publications }\end{array}$ & Present classification $^{\mathrm{a}}$ \\
\hline Gigaspora margarita & Unchanged \\
Glomus constrictum & Septoglomus constrictum \\
Glomus deserticola & Septoglomus deserticola \\
Glomus etunicatum & Claroideoglomus etunicatum \\
Glomus intraradices & Rhizophagus intraradices, \\
& Rhizophagus irregularis \\
Glomus mosseae & Funneliformis mosseae \\
Glomus versiforme & Diversispora epigaea \\
Scutellospora calospora & Unchanged \\
\hline
\end{tabular}

${ }^{\text {a }}$ Following classification by Redecker et al (2013)

${ }^{\mathrm{b}}$ In the majority of cases, the name $G$. intraradices was in the past misapplied to a species nowadays known as $R$. irregularis, and not to $R$. intraradices which has a very limited distribution (Stockinger et al. 2009). publication except in cases where DNA sequences allow unequivocal assignment to currently recognized taxa.

\section{Enhancement of growth and nutrition}

\subsection{AM symbiosis reduce the need of fertilizers}

Vine nutrition is essential as it determines vine functioning and wine quality. Fertilization is complex and highly dependent on plant material, soil characteristics, and the type of production (table grapes, vines, etc.). Most of the vineyard soils are poor in nutrients, and annual exports (pruned canes and clusters) have to be considered for that perennial crop planted for several decades.

It is well established that AM colonization occurs mainly under low levels of either plant nutrient status or low levels of soil fertility (mainly P) (Smith and Read 2008). Indeed, in grapevine, high levels of soil fertility (N or $\mathrm{P}$ ) as well as a high plant nutrient status reduce arbuscular mycorrhiza colonization (reviewed by Schreiner 2005b). Moreover, plants' dependency on arbuscular mycorrhiza for nutrients could depend on root architecture and mainly root hairs, according to the Baylis hypothesis developped for magnaloid (Baylis 1975). Grapevine root architecture was described as having a low density and large diameter fine roots (Richard 1983; Smart et al. 2006), albeit depending on rootstock and cultural practices (Smart et al. 2006; Southey and Archer 2015). Following Baylis hypothesis (Baylis 1975), AM could therefore be highly beneficial by extending the volume of the explored soil allowing an adequate uptake of water and nutrients such as phosphate (Schreiner 2005b). Once the plants colonized, nutrients can be absorbed via two pathways that could operate independently, the root uptake pathway, and the arbuscular mycorrhiza pathway involving the extraradicular fungal mycelium. Fungal mycelium increases the exploitable soil volume and since individual hyphae have diameters comparable to root hairs, they allow access to soil pores that would have been otherwise unexplorable (Smith and Read 2008).

\subsection{AM symbiosis enhances $P$ uptake}

Grapevine phosphorus deficiency is usually rarely observed, not only mainly because of limited phosphorus requirement, but also because of sufficient phosphorus richness in the majority of vineyard soils and remobilization from bark, wood, and roots during periods of high P demand (Jackson, 2014). Nevertheless, $\mathrm{P}$ deficiencies have been described in vineyards in Australia (Tulloch and Harris 1970), France (Champagnol 1978), Germany (Gärtel 1965), and USA (Cook et al. 1983). Phosphorus deficiency symptoms correspond to stunted shoot growth, decrease in dry matter, and berry clusters (Skinner and Matthews 1989). Conversely, it cannot be concluded that high 
soil phosphorus concentrations lead to a better wine quality (Reynolds 2010). P deficiency mainly occurs in acidic soils that are favorable for fixing phosphorus as well as in higher rainfall areas or following fumigation of low phosphorus soils (Menge et al. 1983). In such acidic and/or low phosphorus soils, applying fertilizers containing phosphorus is needed to avoid deficiency symptoms (Conradie 1988). It is well established that AMF can make a significant contribution to $\mathrm{P}$ uptake (Smith et al. 2011). The main form of $\mathrm{P}$ absorbed by plants is the soluble $\mathrm{Pi},\left(\mathrm{HPO}_{4}{ }^{2-}\right)$, resulting from the slow breakdown of organic forms transformed by soil microorganisms. Pi availability is generally low because of its very slow diffusion through soil solution. Indeed, availability can be reduced by fixation in soils with high levels of calcium or by bounding to organic matter or soil particles. Moreover, once absorbed by roots, a depletion zone might appear around them, thus impairing plant nutrition and growth (Nye and Tinker 1977). In mycorrhizal roots, the extraradical mycelium forms an extensive network beyond the root depletion zone, thus shortening the distance for the diffusion of $\mathrm{Pi}$ in soil (Harrison 1999). Indeed, an increase in P levels in either roots or leaves was observed in almost all studied grapevines in the presence of AMF (for review, see Schreiner 2005a; Khalil 2013). It must be kept in mind that although $P$ uptake does not depend on soil $\mathrm{pH}$ or texture, AM colonization of grapevine, and in turn $\mathrm{P}$ uptake, could be reduced for $\mathrm{pH}$ values ranging from 5 to 5.5 (reviewed by Schreiner 2005b). Moreover, it has been reported that total $\mathrm{P}$ levels in grapevine could depend on the AMF species (Biricolti et al. 1997) or isolates (Biricolti et al. 1997; Mortimer et al. 2004; Schreiner, 2005b), but the growth effect cannot be systematically linked to an increase in P concentrations, suggesting that plant growth stimulation is not linked with a greater absorption. Since it has been reported that cytokinin-like compounds are produced by G. mosseae (Barea and Azcon-Aguilar 1982), it can be hypothesized that changes in the hormonal balance following arbuscular mycorrhiza inoculation could control root growth and the root:shoot ratio (Fusconi 2014). However, the involvement of AMF in the hormonal regulation of grape development still has to be investigated.

Although not yet reported for grapevine, it is well established that arbuscular mycorrhiza colonization leads to the specific induction of Pi transporters in root cortical cells (Javot et al. 2007). The arbuscular mycorrhiza pathway can play a major role in $\mathrm{P}$ uptake by arbuscular mycorrhizacolonized plants as all of the $\mathrm{P}$ were delivered via the mycorrhizal pathway when $G$. intraradices was the fungal symbiont of three different plant partners (Smith 2003), indicating a loss of function of the direct uptake pathway in roots colonized by AMF. The mechanism of such a shift in arbuscular mycorrhiza roots is still unclear. Interestingly, a proteome analysis of grapevine $\mathrm{SO} 4$ rootstock upon colonization by two separate fungal species revealed that AMF colonization results in a more drastic reprogramming of host genes than in herbaceous plants (Cangahuala-Inocente et al. 2011). Indeed, several proteins involved in plant adaptation to P deficiency, and previously reported as induced upon P starvation were downregulated, strongly suggesting that grapevine reprioritizes its $\mathrm{Pi}$ uptake strategies to take advantage of $\mathrm{P}$ transfer via the fungal partner (Cangahuala-Inocente et al. 2011).

\subsection{AM symbiosis enhance $\mathrm{N}$ uptake}

Although nitrogen input is usually minimized to limit the growth of grapevine aerial parts and susceptibility to diseases, $\mathrm{N}$ capture from the soil is crucial for vine metabolism and building up of wood reserves (Wermelinger et al. 1991). Furthermore, among soil elements picked up by the roots, nitrogen is the one that influences the most both vine development and grape composition (Reynolds, 2010). For example, low nitrogen availability is not favorable to white wine (sauvignon) quality (Choné et al. 2006). Adequate N supplies are usually needed to allow rapid development of young replant grapevines and to ensure rapid shoot growth in the spring. Since nitrogen uptake depends on soil type and organic matter turnover and thus can be considered as a terroir characteristic, a better understanding of $\mathrm{N}$ uptake would therefore help optimizing $\mathrm{N}$ supply and limiting the use of $\mathrm{N}$ fertilizers. Within this frame, it is now established that arbuscular mycorrhiza can also play a major role in $\mathrm{N}$ uptake (Smith et al. 2010), although the role of $\mathrm{N}$ in AM symbiosis is less clear than that of $\mathrm{P}$. AM fungi are able to take up both $\mathrm{NO}_{3}{ }^{-}$and $\mathrm{NH}_{4}{ }^{+}$, as well as organic N. However, a preference for $\mathrm{NH}_{4}{ }^{+}$ has been reported since $\mathrm{NH}_{4}^{+}$supply reduces $\mathrm{NO}_{3}{ }^{-}$uptake (Johansen et al. 1992; Johansen et al. 1996; Toussaint et al. 2004; Gachomo et al. 2009). This can partly be explained by the energy cost needed for reducing $\mathrm{NO}_{3}{ }^{-}$to $\mathrm{NH}_{4}{ }^{+}$before its incorporation into organic compounds (Marzluf 1997). Indeed, mycorrhizal plants may display better growth with $\mathrm{N}$ supplied as $\mathrm{NO}_{3}{ }^{-}$. In grapevine, mycorrhizal $\mathrm{N}$ uptake from the soil can also enhance plant biomass (Karagiannidis et al. 2007). The form of $\mathrm{N}$ fertilization can influence the dry weight of mycorrhized vines. Indeed, mycorrhized vines had a greater dry weight with $\mathrm{NO}_{3}{ }^{-}$(the best $\mathrm{N}$ source being $\mathrm{Ca}\left(\mathrm{NO}_{3}\right)_{2}$ ) compared to other $\mathrm{N}$ forms, while urea significantly reduced both AMF root colonization and sporulation. Interestingly, grapevine mycorrhizal dependency was the same whatever the $\mathrm{N}$ source (Karagiannidis et al. 2007).

Besides inorganic $\mathrm{N}$ uptake, it is well established that AMF can draw substantial amounts of $\mathrm{N}$ from decomposing organic materials (Hodge and Fitter 2010). Organic nitrogen represents a large proportion of total soil N. Indeed, in organic vineyards, incorporation of legume crop residue is used as a primary mean of modifying soil fertility (Cheng et al. 2008). In the absence of $\mathrm{N}$ fertilization only, total $\mathrm{N}$ uptake from the residue was significantly enhanced by the fungus: A 
significant increase in the percentage of $\mathrm{N}$ derived from the residue was noted in grapevine leaves in response to hyphal proliferation (Cheng et al. 2008). However, although the ability of AMF to take up organic $\mathrm{N}$ in the form of arginine has been recently reported (Fellbaum et al. 2012), direct uptake of organic $\mathrm{N}$ might not be the main $\mathrm{N}$ uptake pathway, and organic $\mathrm{N}$ could be mineralized before it is absorbed by hyphae (Hawkins et al. 2000; Smith et al. 2011).

\subsection{Impact of AM symbiosis on the uptake of other nutrients}

Among the other chemical elements essential for grapevine growth, potassium $(\mathrm{K})$, magnesium $(\mathrm{Mg})$, zinc $(\mathrm{Zn})$, and boron (B) are important for fertilization. Potassium deficiency occurs in high calcium ( $\mathrm{Ca}$ ) or $\mathrm{Mg}$ containing soils, as well as in high rainfall regions. Low-containing $\mathrm{K}$ vines are more drought-prone and cold-sensitive (Reynolds 2010). Zinc deficiency, due to reduced solubility in alkaline soils, leads to poor fruit set (Reynolds 2010). B deficiency occurs in sandy soils where excessive leaching occurs following rainfall or irrigation (Jackson 2014). Other chemical elements, iron (Fe), manganese (Mn), and sulfur (S), although highly necessary for harmonious growth and development, are rarely deficient in vineyard soils (Christensen 2000). However, certain cultural practices or soil properties can impair nutrient uptake. Indeed, it has been reported that nitrogen fertilization depressed the uptake of some elements such as B and Mn. Ca deficiency symptoms are uncommon but can occur in strongly acidic soils, below pH 4, while Fe deficiency symptoms (limeinduced chlorosis) are normally found in calcareous soils for sensitive rootstocks (Jackson 2014).

Data relying on the role of AMF in the uptake of other soil nutrients by grapevine are scarce. Macro- and micro-nutrient uptake could depend partly not only on the fungal partner, but also on the host plant. In studies on the interaction between arbuscular mycorrhiza infection and soil lime content, arbuscular mycorrhiza inoculation of Kober 5BB rooted cuttings with three different Glomus species (G. constrictum, $G$. deserticola, and G. mosseae) resulted in an increase in leaf copper $(\mathrm{Cu})$ concentrations and in a decrease in $\mathrm{B}, \mathrm{Mn}$, and $\mathrm{Zn}$ concentrations, $\mathrm{Mn}$ and $\mathrm{Zn}$ depending on the fungus (Biricolti et al. 1997). In another set of experiments, $\mathrm{Ca}$ and $\mathrm{K}$ concentrations increased in mycorrhizal Victoria grapevine grafted onto rootstocks 3309C or 110R (Nikolaou et al. 2002). Similarly, inoculation of different grapevine rootstocks with the fungus Gigaspora margarita showed that inoculation tended to increase $\mathrm{K}$ concentrations in all rootstocks but decreased $\mathrm{Ca}$ and $\mathrm{Mg}$ concentrations in tetraploid rootstocks only. Surprisingly, the place of the inoculum was reported to modulate both nutrient uptake and grapevine growth (Petgen et al. 1998). Indeed, leaf blade $\mathrm{Zn}$ and $\mathrm{P}$ concentrations and the shoot dry weight significantly increased when the inoculum was placed in the top soil while only $\mathrm{Zn}$ and $\mathrm{Cu}$ concentrations increased when the inoculum was placed in $36-45 \mathrm{~cm}$ soil depth (Petgen et al. 1998). This suggests that colonization levels would be a determining factor in modulating AM-induced nutrient uptake and plant growth. It has also been reported that the content of most nutrients in grapevine cuttings (Pinot noir) was significantly increased depending on the soil type (Schreiner, 2005b). Indeed, $\mathrm{P}, \mathrm{K}, \mathrm{Ca}, \mathrm{Mg}, \mathrm{Fe}$, and $\mathrm{B}$ contents were increased only in a low $\mathrm{P}$ soil. This effect would be linked to the primary stimulation of $\mathrm{P}$ uptake and resulting growth stimulation. However, since accumulation of $\mathrm{S}, \mathrm{Zn}$, and $\mathrm{Cu}$ also occurred in high $\mathrm{P}$ soil, uptake mechanisms independent of P-induced growth effects might exist.

Interestingly, when two G. mosseae isolates from two different soils were used to inoculate grapevine cuttings, only the native one from the high $\mathrm{P}$ soil enhanced $\mathrm{Cu}$ and $\mathrm{S}$ uptake (Schreiner, 2005a). These results suggest that the selection of appropriate inocula for specific functions would be the best strategy for inocula producers.

Although AM-induced increases in chemical elements could be linked to the fungus hyphae, decreases in ionic concentrations would involve several mechanisms. Decreased ionic concentrations could result from a dilution effect following increased growth in response to P uptake (Smith and Read 2008). However, since the concentrations of some ions increased following arbuscular mycorrhiza inoculation in some of the experiments described above, the "ion decrease" effect is unlikely to occur and other mechanisms probably operate. Indeed, experiments with maize showed that AMF could affect the populations of $\mathrm{Fe}$ - and $\mathrm{Mn}$-reducing microorganisms in the rhizosphere. As a result, Mn-reducing potential or the amount of reduced $\mathrm{Mn}$ in the soil, and hence $\mathrm{Mn}$ availability for plants, decreased (Kothari et al. 1991). Evidence for such interactions between microorganisms regarding nutrient uptake in the grapevine mycorrhizosphere is currently missing. Interestingly, inoculation of grapevine with $G$. mosseae in replant soil significantly stimulated the growth of vegetative aerial parts, while the number of fluorescent pseudomonads dropped (Waschkies et al. 1994). However, no changes in leaf mineral concentrations ( $\mathrm{P}, \mathrm{K}, \mathrm{Ca}, \mathrm{Fe}$, or $\mathrm{Mn}$ ) were observed following arbuscular mycorrhiza inoculation, suggesting that plant growth stimulation mainly resulted from the arbuscular mycorrhiza-induced reduction of pseudomonads present in replant soil, rather than in nutrition enhancement (see in the mycorrhiza-induced resistance part).

\subsection{How does grapevine cope with AM symbiosis carbon cost?}

The $\mathrm{C}$ costs of the fungal partner can be considerable in arbuscular mycorrhiza symbiosis since the fungus can receive 4 to $20 \%$ of the plant's photosynthetically fixed C (Smith and Read 2008). Grapevine, as a deciduous plant, mainly relies on 
stored $\mathrm{C}$ for growth of new tissues, mainly in spring (Buttrose 1966). Since AMF growth and nutrient acquisition also rely on host plant reserves, $\mathrm{C}$ reserve mobilization and plant development could be significantly influenced by the AMF (reviewed by Smith et al. 2010). Therefore, when arbuscular mycorrhiza costs exceed the nutritional benefit to the host, a negative growth response can occur (Smith et al. 2010). In grapevine, a detailed analysis revealed that a negative growth response might occur during the first 2 months of colonization with Glomus etunicatum (Mortimer et al. 2005). The C taken up by the AMF was devoted to the growth and development of new fungal structures and spores. This $\mathrm{C}$ drain during rapid root colonization had a negative impact on host stem growth before colonization was maximum. Once the plateau of arbuscular mycorrhiza development was reached, C drain from stem tissues stopped, and then the stem reserves were refilled. Once symbiosis is functional, more $\mathrm{C}$ can be used for nutrient acquisition (Mortimer et al. 2005; Gilbert et al. 2014). Such a negative response following the first 2 months of arbuscular mycorrhiza colonization is thought to be transient in grapevine as a significant increase in growth was recorded 112 days after inoculation of seven rootstocks and two ungrafted cultivars with four arbuscular mycorrhizal fungi (Lindermann and Davis 2001). Growth increase varied with individual rootstocks and cultivars and ranged between 64 and $220 \%$. The largest growth increase was observed with G. intraradices.

Rapid growth response following inoculation could also depend on the fungus. Shoot biomass was enhanced after 5 weeks in grapevines inoculated with either $G$. intraradices or G. mosseae (Cangahuala-Inocente et al. 2011). Beyond nutrient uptake stimulation, arbuscular mycorrhiza colonization most probably increases photosynthetic rates in grapevine (Mortimer et al. 2005) as in other plant systems such as Trifolium (Wright et al. 1998; Schreiner 2005b; Smith and Read 2008). Unfortunately, data relying on arbuscular mycorrhiza and photosynthetic activity in grapevine are scarce (Bavaresco et al. 2003) and puzzling. Surprisingly, although vines exhibited greater shoot and root growth compared to the control, leaf chlorophyll contents remained either reduced or unchanged by AMF, depending on the fungus (Biricolti et al. 1997; Smith and Read 2008). However, arbuscular mycorrhiza applications could increase plant soluble sugars contents (Cetin et al. 2014) that do not only act on the metabolic activities of the host but also as a signal regulators in processes related plant growth and development (Jang and Sheen 1997; Loreti 2001). Moreover, AMF may induce changes in hormonal balance, leading to an increase in cytokinin content responsible for greater vegetative development (Biricolti et al. 1997; Harrison 1999).

Studies on the physiological effects of inoculation of grapevines with $\mathrm{AMF}$ reveal that symbiosis enhances plant growth in almost all cases (Motosugi et al. 2002; Schreiner 2005b;
Ridgway et al. 2006; Karagiannidis et al. 2007; CangahualaInocente et al. 2011). Nevertheless, the arbuscular mycorrhiza-dependent enhancement of grapevine growth as a whole, or of grapevine roots only, varies with rootstock and fungus (Lindermann and Davis 2001; Smith and Read 2008; Nogales et al. 2009; Cangahuala-Inocente et al. 2011). Moreover, in field conditions, the physical, chemical, and biological composition of the replant soil (mycorrhizal propagules, pathogenic fungi) might be crucial in controlling the effects of arbuscular mycorrhiza inoculation (reviewed by Schreiner 2005b; Nogales et al. 2009). Although plant growth was enhanced at the end of the first year after planting for two different arbuscular mycorrhiza-inoculated rootstocks, no more differences were reported after the second year for one of the rootstocks (Smith and Read 2008; Nogales et al. 2009). Plants could achieve optimal growth after being colonized by native fungal propagules and thus no longer benefit from artificial inoculation. Therefore, a preliminary study of the native inoculum present in the replant soil is essential before considering the suitability of arbuscular mycorrhiza inoculation.

\section{Increase of tolerance to abiotic stresses}

Abiotic stresses cause extensive losses to agricultural productivity. Grapevine is no exception to the rule and faces several abiotic stresses throughout its lifespan. Drought, salinity, or heavy metals are serious problems in many parts of the world. The potential of AMF to enhance plant tolerance to abiotic stress conditions has long been known (Smith and Read 2008), and their use in sustainable agricultural systems will be of tremendous importance for soil quality and crop productivity under severe edapho-climatic conditions (Lal 2009).

\subsection{AM symbiosis alleviate grapevine water stress}

Soil water status and plant water use play a key role in grapevine growth and yield and in grape quality. However, since vineyards are mainly located in areas of dry climate during the growing season, water deficit frequently occurs. Moreover, according to the global climate models (IPPC 2014), in the near future, water deficit may become a limiting factor for grapevine development and wine quality. Indeed, climate change was already shown to influence on grape phenology (Jones and Davis 2000; Webb et al. 2007). Whereas moderate water stress during maturation has a positive effect on grape quality (Chaves et al. 2010), prolonged water stress may have a strong negative effect on photosynthesis and yield. Therefore, in some vineyards, vines require additional irrigation in key periods to limit water deficit stress. Vineyard management strategies thus play a determining role in the capability of soils to retain nutrients and water. AMF are known to improve water uptake by plants and nutrient uptake at the same time 
(Kohler et al. 2008; Adesemoye et al. 2008). An effective development of external mycelium and/or arbuscules can be crucial in dry situations. In irrigated vineyards, regulated deficit irrigation (RDI) is commonly applied in order to control vegetative development and improve fruit quality. When an additional water deficit was applied to RDI, the frequency of arbuscules was greater than in the standard RDI plot although fine root production was reduced, indicating that grapevines compensated for a lower density of fine roots by increasing arbuscular colonization (Schreiner et al. 2007). As RDI treatments did not have a significant effect on aboveground vine growth, yield, or fruit quality, it appeared possible to produce high-quality wine grapes with less irrigation or in arid climates. However, the mechanisms of improved water uptake are as yet unclear, no arbuscular mycorrhiza-specific or arbuscular mycorrhiza-inducible aquaporin gene has been identified so far in microarray studies. However, although there is no current evidence of direct water transfer to plants via arbuscular mycorrhiza fungal hyphae, increased water use efficiency in arbuscular mycorrhiza plants has been reported in several studies including studies on grapevine.

In coarse-rooted plants such as grapevine, the beneficial effect of arbuscular mycorrhiza symbiosis is crucial and relies more on arbuscular mycorrhiza symbiosis than for fine-rooted plants (Bolan 1991; Eissenstat 1992). For example, in a Hungarian vineyard, Donkó et al. (2014) reported that the degree of mycorrhizal colonization is higher in drier soil areas. Arbuscular mycorrhiza-colonized grapevine roots can exhibit more efficient water uptake and allow grapevine to cope with water stress. During drought stress, although arbuscular mycorrhiza colonization declined, the biomass and the proline content were higher in arbuscular mycorrhiza plants than in non-arbuscular mycorrhiza plants (Valentine et al. 2006). Surprisingly, in these conditions, similar photosynthetic rates were observed despite lower stomatal conductance and substomatal $\mathrm{CO}_{2}$ concentrations in arbuscular mycorrhiza grapevines, clearly indicating that under drought stress, water use efficiency was higher in arbuscular mycorrhiza plants. The photosynthetic response of arbuscular mycorrhiza plants might be associated with higher Rubisco activity and electron transport rates. In two woody European species (Olea europaea and Rhamnus lycioides), the effects of arbuscular mycorrhiza inoculation on water use efficiency have been reported to depend not only on the plant species but also on the composition of the inoculum (Querejeta et al. 2006). These results highlight a "functional diversity" in arbuscular mycorrhiza symbioses that should be taken into account when optimizing arbuscular mycorrhiza colonization protocols, especially in the field. Surprisingly, the significant increase of the water flux in arbuscular mycorrhiza plants appears to be independent of changes in the nutrient status of the host plant (Read 1992; Sylvia and Williams 1992; Koide and Dickie 2002). The same situation was reported for young transplanted grapevines. In 1-year-old arbuscular mycorrhiza-colonized grapevines, the water flux (stomatal conductance, transpiration rate, and xylem conductance) and photosynthesis rate increased compared to non-arbuscular mycorrhiza grapevines, although no increase in biomass or mineral nutrition was recorded (van Rooyen et al. 2004). These results indicate that arbuscular mycorrhiza inoculation can enhance the plant water relations and the photosynthesis performance of transplanted grapevine rootstocks, thus potentially alleviating the transplanting shock and increasing potential survival. This improved drought tolerance is of special importance for transplanted plants in which root systems are less extended and more superficial during the first years of growth.

Although AM can enhance water uptake, thus improving drought tolerance, the expected benefit of the symbiosis would depend on the rootstock. It is established that while most roots are produced in spring when soil temperatures are favorable, root development is rootstock-dependent since some do produce roots during the warm dry season, at deeper depths, thus improving water foraging and transport (Smart et al. 2006). Such grapevines are likely less AM-dependent for water uptake. In dry soils, the root extension rate is lower because of reduced turgor and increased soil strength, as well as reduced nutrient availability (Viets 1972). In these situations, the development of extraradicular mycelium can be crucial for optimizing nutrient uptake. Improved drought tolerance is closely linked to improved nutrition (especially $\mathrm{P}$ ) of arbuscular mycorrhiza plants. Arbuscular mycorrhiza plants indeed grew better under drought stress than NM plants (Augé 2001). In sorghum, regardless of the plant water status, arbuscular mycorrhiza roots were able to absorb P more efficiently from dry soil than NM roots (Neumann and George 2004). Because hydraulic conductivity of root cortical cells is lower under P deficiency (Radin and Eidenbock 1984; Andersen et al. 1988; Reinbott and Blevins 1999; Radin and Matthews 2004), maintenance of P supply by arbuscular mycorrhiza colonization may also play a role by increasing root hydraulic conductivity and facilitating water uptake.

\subsection{AM symbiosis help grapevine to cope with calcareous soil and iron deficiency}

Iron is in relatively high abundance in the earth's cultivated soils, but plant $\mathrm{Fe}$ acquisition is often impaired that resulted in severe crop losses. Among the soil properties which impair $\mathrm{Fe}$ nutrition, calcium carbonate $\left(\mathrm{CaCO}_{3}\right)$ plays a major role (Loeppert et al. 1994). High concentrations of bicarbonate ions, called active carbonate or active lime (Drouineau 1942), in calcareous soils reduce iron availability, with subsequent chlorosis that can seriously impair grapevine yield and quality (Bavaresco et al. 2006). The best way to avoid chlorosis risks in these soils is to select lime-tolerant rootstocks (Tagliavini and Rombolà 2001). A factorial experiment aimed 
at determining the influence of AMF on the tolerance of the rootstock Kober 5BB to lime-based soils. Interestingly, it revealed that mycorrhization always increased vegetative growth independently of the lime concentration compared to the control, but did not reduce the grapevine susceptibility to chlorosis (Biricolti et al. 1997). The greater growth of mycorrhizal plants was not linked to increased photosynthesis since the chlorophyll content was higher in control plants even when the soil did not contain lime. Leaves of inoculated plants had higher levels of visual chlorosis whatever the lime concentration, except for one Glomus species (Glomus deserticola).

In contrast, in susceptible rootstocks, arbuscular mycorrhiza inoculation may be another way to alleviate chlorosis symptoms on calcareous soils by controlling the chlorophyll content (Bavaresco et al. 2006). Chlorophyll content and iron uptake increased in the lime-susceptible rootstock 101-14 inoculated with $G$. mosseae and then grown alone or grafted with Chardonnnay clone R8 (Bavaresco et al. 2010). Furthermore, inoculation of the susceptible graft combinations Pinot blanc/ 101-14 or Pinot blanc/3009C also brought about increased chlorophyll and $\mathrm{Fe}$ contents and reduced chlorosis symptoms (Bavaresco et al. 2010). Inoculating grapevine with AM fungi to alleviate lime-induced chlorosis in vineyard is a promising technique that requires further studies.

\subsection{AM symbiosis increase grapevine tolerance to soil salinity}

Soil salinity refers to the amount of dissolved salts in soils and is one of the major abiotic factors limiting viticulture productivity, mainly in arid and semi-arid zones of the Mediterranean basin (Belew et al. 2010). The main effects of salinity are: (i) the development of an osmotic stress that greatly impairs plant transpiration and photosynthesis (Shannon and Grieve 1998) and (ii) the induction of changes in the mineral balance leading to metabolic dysfunctions and altered physiological mechanisms (Hasegawa et al. 2000), leading to limiting plant growth. Saline soil conditions occur naturally in some vineyards. It could be due to primary salinization that occurs naturally when the soil parent material is rich in soluble salts. Moreover, salt-affected soils often occur on irrigated vineyards, especially in arid and semi-arid regions, due to the insufficient leaching, improper irrigation, poor drainage, or irrigation water high in salts. For example, in Australia, the major ions in irrigation water are sodium $\left(\mathrm{Na}^{+}\right)$and chloride $\left(\mathrm{Cl}^{-}\right)$(Walker et al. 2010). Therefore, viticultural practices should be adapted to minimize the uptake and accumulation of those problematic ions in grapevines. Grapevine, by comparison with other crop types, is classified as moderately sensitive to salinity (Maas and Hoffman 1977). However, high salinity considerably inhibits shoot growth and affects berry quality (Walker et al. 2002).
It has been well established that AMF occur naturally in saline environments (García and Mendoza 2007) and alleviate salinity stress in many plant cultures such as banana, Vicia $f a b a$, tomato, olive, Sorghum, Lotus, and palm oil tree (Yano-Melo et al. 2003; Rabie 2005; Al-Karaki 2006; Bouamri et al. 2006; Cho et al. 2006; and Sannazzaro et al. 2006; Porras-Soriano et al. 2009) by improving uptake of nutrients such as $\mathrm{P}, \mathrm{N}, \mathrm{Zn}, \mathrm{Cu}$, and $\mathrm{Fe}$. The improvement in the plant $\mathrm{P}$ status is probably the most important source of salinity stress tolerance in arbuscular mycorrhiza-colonized plants (Giri et al. 2003; Giri and Mukerji 2004), even if other physiological processes occur concomitantly (Feng et al. 2002; Ruiz-Lozano 2003; Giri and Mukerji 2004; Giri et al. 2007). Indeed, when AM-colonized grapevines were irrigated with saline solutions, AM was observed at all salt levels used, albeit decreasing with increasing $\mathrm{NaCl}$ concentrations (Khalil 2013). Moreover, although salinity reduced grapevine growth, vegetative growth increased as a result of AMF inoculation whatever the rootstocks studied. These results clearly indicate the beneficial role of AM symbiosis in improving grapevine salt tolerance (Belew et al. 2010; Khalil 2013).

\subsection{AM symbiosis increase grapevine tolerance to heavy metals}

Copper-based fungicides have been used intensively in Europe since the end of the nineteenth century to control vine fungal diseases, especially downy mildew, and their long-term application and subsequent wash off from treated plants have led to considerable $\mathrm{Cu}$ accumulation up to toxic concentrations in vineyard surface soils (Komárek et al. 2010). Whereas arable land usually presents quantities of $\mathrm{Cu}$ varying between 5 and $30 \mathrm{mg} \mathrm{kg}^{-1}$ of $\mathrm{Cu}$, the soils of numerous wine-growing areas could contain as much as 200 to $500 \mathrm{mg} \mathrm{kg}^{-1}$ of $\mathrm{Cu}$ (Brun et al. 1998). For example, $\mathrm{Cu}$ concentrations ranging from 130 to $1280 \mathrm{mg} \mathrm{kg}^{-1}$ have been detected in the surface soil of European vineyards with an established history of copper-based fungicide use (Magalhães et al. 1985; Deluisia et al. 1996; Flores-Vélez et al. 1996; Besnard et al. 2001), Cu concentrations in Australian vineyard soils were generally much lower (6-150 $\mathrm{mg} \mathrm{kg}^{-1}$ ) (Wightwick et al. 2008), whereas $\mathrm{Cu}$ concentrations as high as $3216 \mathrm{mg} \mathrm{kg}^{-1}$ have been found in Brazil (Mirlean et al. 2007). Although this increased $\mathrm{Cu}$ availability does not appear to change grapevine nutritional status (Miotto et al. 2013), it has a negative influence on the soil flora and fauna and may lead to phytotoxicity in acidic soils, leaf oxidative stress, yield losses, and poorer wine quality (Ninkov et al. 2012). In practice, soil copper is not expected to induce phytotoxicity in mature grapevines as their root systems extend below the surface soils where most of the applied copper tends to remain. In contrast, young vines may be affected as their root systems are much shallower while establishing. In this context, $\mathrm{Cu}$ may have phytotoxicity 
implications for vine nurseries or when vineyards are replanted (Conradie 2004).

Metal-tolerant AMF have been isolated from polluted soils. These indigenous populations cope better with metal toxicity than those isolated from unpolluted soils (del Val et al. 1999; Meier et al. 2011). To persist in environments with high metal content, AMF have evolved a series of strategies to avoid damage caused by metals and survive in $\mathrm{Cu}$-polluted environments (Ferrol et al. 2009; Cornejo et al. 2013). AMF inoculation has become a prospective tool for enhancing plant tolerance to environmental stress conditions in metal-contaminated soils. Many examples from the literature illustrate this role of arbuscular mycorrhiza symbiosis, but progress towards understanding the cellular mechanisms utilized by AMF to metabolize heavy metals and alleviate their cytotoxicity has been made only recently (Lanfranco 2002), and the underlying mechanisms are not yet fully understood (Khade and Alok 2009). For example, the occurrence of AMF in Nihyperaccumulating plant species naturally found on metalrich soils offers possibilities of using heavy metal-hyperaccumulating plants together with AMF for phytoremediation strategies (Göhre and Paszkowski 2006). In another way, AMF not only improve $\mathrm{Pi}$ or $\mathrm{N}$ uptake by roots through their mycelium network but also have a buffering effect on $\mathrm{Cd}$ uptake and thus reduce the toxic effect of $\mathrm{Cd}$ on plant growth (Rivera-Becerril et al. 2002; Lopez-Millan et al. 2009). Immobilization of metals in the fungal biomass is proposed as a major mechanism whereby AMF may increase plant tolerance to heavy metals. Mycorrhizal roots may act as a barrier against metal transport, reducing transfer and enhancing root/shoot $\mathrm{Cd}$ ratios (de Andrade et al. 2008). This effect is attributed to metal adsorption onto hyphal walls because chitin has an important metal-binding capacity (Joner et al. 2000; Christie et al. 2004). In soil, glomalin, a glycoprotein produced by AMF, may have a metal-chelating function and thereby diminish metal availability for plants (González-Chávez et al. 2004; Khan 2006).

AMF play a significant ecological role in the phytostabilization of potentially toxic trace element-polluted soils through sequestration mechanisms and, in turn, help mycorrhizal plants to survive in polluted soils. Their potential role in phytoremediation of heavy metal-contaminated soils is also emerging, and we can expect them to be useful in $\mathrm{Cu}$-contaminated vineyard soils. Moreover, since AMF are present on the roots of plants growing on such types of soils, isolation of indigenous $\mathrm{Cu}$ stress-adapted AMF could be a potential biotechnological tool for inoculating plants in disturbed ecosystems.

\section{Protection against biotic stresses}

Most grown grapevine varieties ( $V$. vinifera cvs) are susceptible to cryptogamic diseases such as downy mildew, causing great yield losses and require numerous fungicide treatments. However, pesticides are often only partially effective against soil-borne diseases and they are detrimental to human health and to the environment. Some of them are now forbidden in some countries, as fumigants and winegrowers have no more solution to fight soil pathogens.

Plants can develop an enhanced defensive capacity after infection by AMF. This "mycorrhiza-induced resistance" (MIR) could provide systemic protection against a wide range of biotrophic and necrotrophic pathogens, nematodes, and herbivorous arthropods (Cameron et al. 2013 for review). Therefore, AMF can suppress or reduce plant pests and diseases through the induction of systemic resistance (Pozo and Azcon-Aguilar 2007; Pineda et al. 2010; Jung et al. 2012). Depending on the plant/pathogen/AMF interaction, MIR could be associated with systemic acquired resistance (SAR)-like priming of salicylic acid (SA)-dependent genes (Khaosaad et al. 2007; Gallou et al. 2011), but more often coincides with priming of jasmonic acid (JA)-dependent defenses, especially in grapevine ( $\mathrm{Li}$ et al. 2010; Hao et al. 2012). In this case, MIR is thought to result from the active suppression of components in the SA-dependent defense pathway, causing systemic priming of JA-dependent defenses (Pozo and Azcon-Aguilar 2007). Cameron et al. (2013) presented a spatiotemporal model of MIR that differentiated four major steps. During the first step, plant root exudation of strigolactones (a class of terpenoid lactones) induces hyphal branching in AMF, thereby helping the fungus to localize host roots and facilitating infection. Then (step 2), AMF initiate infection of the root cortex, and microbe-associated molecular patterns (MAMPs) from the mycorrhizal fungus are recognized by the plant innate immune system. A recent study (Wang et al. 2014) moreover reported that, in rice, a bifunctional plant receptor (OsCERK1) regulates both chitintriggered immunity and arbuscular mycorrhizal symbiosis, suggesting that a single receptor could balance defense and symbiosis. This perception step leads to transient expression of MAMP-triggered immunity and generation of longdistance signals in the vascular tissues, which induce longlasting priming of SA-dependent defenses and SAR. At this stage, AMF use specific effector molecules and stimulate abscisic acid (ABA) production in the roots to suppress MAMP-triggered immunity locally. ABA can be transported through the xylem to the aerial parts of the plant (shoot), where it can prime cell wall defenses to protect the plant against further aerial pathogen attacks. Moreover, formation of intracellular arbuscules increases transport of photosynthates (sugars) to the roots and improves phosphate uptake, hence quantitative and qualitative changes in the chemical composition of root exudates. The combination of all these effects leads to changes in root exudation chemistry and recruitment/selection of specific mycorrhizosphere bacteria. In the fourth and last step, the establishment of the 
mycorrhizosphere goes along with dense colonization by selected bacteria (including Pseudomonas and Burkholderia strains) that metabolize mycorrhizal root exudates and deliver induced systemic resistance (ISR)-eliciting signals to the root surface and/or fungal hyphae. The perception of these signals by the host plant generates long-distance signals that prime jasmonate- and ethylene-dependent plant defenses and induce ISR. Bioprotection of mycorrhizal plants can be active against a wide spectrum of pathogens; therefore, management of AMF can be considered as an ecosystemic service (Fig. 3) and could complement innovative protective strategies.

In the case of grapevine, MIR has been described mainly against root pathogens and especially against the fungi Armillaria and Cylindrocarpon spp. For example, local and systemic MIR was evidenced against the ectoparasitic nematode Xiphinema index, the vector of grapevine fanleaf virus (GFLV) which provokes gall formation and severe damage to the root system (Hao et al. 2012). This study suggests a priming of grapevine rootstock (SO4) defense responses by the arbuscular mycorrhizal fungus $R$. irregularis BEG141 and transmission of a plant-mediated signal to non-mycorrhizal tissues. This bioprotective effect was not linked to an improved $\mathrm{P}$ status of the plant, but directly involved a so far unknown induced systemic factor. White root rot disease (due to Armillaria mellea) symptoms developed more slowly in mycorrhizal ( $G$. intraradices BEG72) grapevine (110R) and exhibited greater root and shoot growth compared to the non-mycorrhizal plants (Nogales et al. 2009). Mycorrhizal plants were therefore more tolerant to A. mellea than nonmycorrhizal ones. The authors revealed that polyamines were probably implied in the early signaling processes of increased tolerance of mycorrhizal plants to the pathogen. Finally, $V$. rupestris inoculated with $G$. intraradices (INVAM CA501) was less susceptible to black foot disease (due to Cylindrocarpon macrodidymum) that non-mycorrhizal ones (Petit and Gubler 2006). By enhancing plant resistance to these biotic stresses, AMF may therefore decrease grape root susceptibility to black foot disease. However, in this study, grapevine root colonization with AMF preceded inoculation with $C$. macrodidymum, so maybe very few root infection sites were available for the pathogen.

\section{Increase of soil stability}

A large number of vineyards are planted on hills and submitted to risks of erosion. In these situations, soil structuration is essential. AMF symbionts grow out from the mycorrhizal root to develop a complex, ramifying network into the surrounding soil which can reach up to $30 \mathrm{~m}$ of fungal hyphae per gram of soil (Cavagnaro et al. 2005; Wilson et al. 2009). This mycelial network can have a binding action on soil particles and improve soil structure. Moreover, the secretion of hydrophobic, "sticky" proteinaceous substances by AMF, consisting of glomalin (Rillig et al. 2002), also contributes to soil stability and water retention (Bedini et al. 2009). Therefore, the combination of all these factors is considered as an important factor that helps stabilize soil aggregates (Andrade et al. 1998; Rillig and Mummey 2006), thereby leading to increased soil structural stability and quality (Caravaca et al. 2006; Bedini et al. 2009; Rillig et al. 2014). In this way, a reduction in fungal biomass will result in a negative effect on soil stability and consequently will increase the risk of soil erosion.

Erosion of cultivated land soil by water is detrimental onsite as well as off-site and poses problems throughout the world. These include soil and nutrient loss (Ramos and Martinez-Casanovas 2004), long-term productivity loss of degraded soils (Lal 1987; Gunatilake 2000), and a wide range of environmental problems arising from sediment delivery to the drainage network and reservoirs. Soil erosion in vineyards is a particularly favorable context for soil loss as compared to other agricultural lands (Le Bissonnais et al. 2001; Brenot et al. 2008). This irreversible soil degradation may cause major environmental and economic damage (Pimentel 1995). For example, Martínez-Casanovas and Ramos (2006) estimated the cost of erosion in vineyard fields in the Penedès-Anoia region (NE Spain), with special focus on on-site effects, i.e., the replacement cost of lost nutrients (loss of fertilizers, mainly $\mathrm{N}$ and $\mathrm{P}$ ) over the year and the cost incurred by drainage channel maintenance and ephemeral gullies that appear in the vineyards as a result of high intensity rainfalls. In economic terms, they concluded that these costs represent respectively $6.6 \%$ (nutrient loss) and $7.8 \%$ (damage to infrastructures) of the grape production income. The replacement value of lost $\mathrm{N}$ and $\mathrm{P}$ represented $2.4 \%$ for $\mathrm{N}$ and $1.2 \%$ for $\mathrm{P}$. In this context, endomycorrhizal fungi may have a double interest, firstly by enhancing soil structural stability (due to the external hypha network and glomalin secretions) and secondly by enhancing $\mathrm{N}$ and $\mathrm{P}$ uptake from the soil and thereby limiting damage related to nutrient losses.

\section{Impact of vineyard agricultural practices on grapevine mycorrhization}

During its life cycle, the grapevine is subject to several cultural practices to allow it to grow in optimum conditions for a given production objective. These practices include, among others, fertilization, soil management, weed vegetation cover (chemical or mechanical weed control, and weed), and pests. With an objective of sustainable viticulture, efforts were made to reduce the use of pesticides and agroecological initiatives such as green, organic, biologic, or biodynamic management have been developed (Altieri 2002). Grapevine mycorrhization therefore looks essential regarding the possible ecosystemic services it can provide to the vineyard. However, viticultural 
practices have to be considered as some of them have true impact on AMF.

\subsection{Impact of soil management practices}

Tillage is known to be a prominent factor in shaping AMF communities in agricultural settings (Verbruggen and Kiers 2010) because it directly affects the integrity of the mycelial network. These effects seem to depend on tillage intensity or depth (Stockinger et al. 2014) and to be modulated by fertilization (Peyret-Guzzon et al. 2015). Certain glomeromycotan species are able to tolerate the recurrent perturbation and thus accumulate in arable soils. Studies on the effects of tillage on AMF in vineyards still remain scarce. Lumini et al. (2010), for instance, used pyrosequencing of soil-derived DNA to analyze AMF communities in a tilled vineyard in comparison to another one covered by vegetation. Interestingly, these authors found that the tilled vineyard soil harbored a higher diversity than the covered vineyard soil. The question arises whether tillage at the soil surface would affect AMF communities active in the roots which grow relatively deeply in the soil. This field of research therefore definitely requires further study.

\subsection{Impact of high fertilizer inputs}

High fertilizer inputs (especially P) are known to reduce AMF root colonization and propagules in many agrosystems, including vineyards (Karagiannidis and Nikolaou 1999). For example, in Oregon vineyards, foliar application of $\mathrm{P}$ was linked to low AMF colonization. Depending on the rootstock, $\mathrm{P}$ sources in soil (calcium bis-dihydrogen phosphate, tricalcium phosphate, aluminum phosphate, and iron phosphate) affected growth and mineral uptake of mycorrhizal grapevines (Nikolaou et al. 2002). Furthermore, grapevine $\mathrm{N}$ fertilization affected AMF colonization and, in turn, affected berry composition. Karagiannidis et al. (2007) indeed compared the impact of different nitrogen fertilizers $\left(\mathrm{CO}\left(\mathrm{NH}_{2}\right)_{2},\left(\mathrm{NH}_{4}\right)_{2} \mathrm{SO}_{4}\right.$, $\mathrm{Ca}\left(\mathrm{NO}_{3}\right)_{2}$, and $\left.\mathrm{NH}_{4} \mathrm{NO}_{3}\right)$. Although the nitrogen form had no effect on non-inoculated plants mycorrhizal grapevine plants had a higher growth response with calcium nitrate as the $\mathrm{N}$ source (see Section 3.3). It is worthwhile to note that urea suppressed AMF root colonization and sporulation.

\subsection{Impact of weeds/cover crops}

Weed control practices are often used in vineyards as alternatives to herbicides. Such ecological practices promote weeds as hosts for soil beneficial microbes (Jordan et al. 2000). As weed control and cover cropping impact vineyard soil communities (Baumgartner et al. 2005; 2010), we could expect AMF diversity and colonization of grapevine to increase with the increasing frequency and diversity of mycorrhizal hosts on the vineyard floor. Bare reality seems to be more complex as at least two studies give opposite results. On the one hand, Baumgartner et al. (2010) revealed that there was no correlation between mycorrhizal colonization of grapevine and frequency of mycorrhizal weeds. The authors suggest that mycorrhizal hosts on the vineyard floor do not significantly influence mycorrhizal colonization or mycorrhizal fungal communities of grapevines. On the other hand, Radic et al. (2012) showed that selected neighboring weeds (Plantago lanceolata L. and Tanacetum cinerariifolium) could influence the formation of arbuscular mycorrhiza in grapevine. They stressed that plant identity and density significantly impact on the development of mycorrhizal intra- and extraradical mycelium and/or sporulation. Therefore, herbaceous weed species could promote a different set of dominant mycorrhizal fungi, potentially providing a wider spectrum of these fungi for colonizing grapevine roots. This study highlights that encouraging host plant diversity in vineyards can be valuable, provided that it does not develop nutrient and/or water competition with grapevine.

\subsection{Impact of pest management practices}

Soil pest management is complex, and the equilibrium between fighting again pests and protecting/promoting beneficial microorganism as AMF is difficult to reach.

Mesocriconema xenoplax is a plant-parasitic nematode that is widely distributed throughout vineyards in the USA, South Africa, and Europe. In Oregon, many of the vineyards have high population densities of Mesocriconema xenoplax (Pinkerton et al. 1999), which may impact the establishment and growth of young vines. Moreover, those nematodes and AMF coexist and interact with grapevine roots and with the rhizosphere. The frequency of grapevine fine roots containing arbuscules was depressed by 5 to $65 \%$ in plants initially infested by this nematode as compared to controls (Pinkerton et al. 2004). Competition for photosynthates within the root system may be a possible mechanism whereby plant-parasitic nematodes lower arbuscule frequency.

In the grape-growing areas of California, soil fumigation with nematicides or biocides (such as methyl bromide) are useful. Fumigation of soils (Menge et al. 1983) could be necessary to alleviate disease problems caused by soil-borne pests (against M. xenoplax or C. macrodidymum especially), even if this practice is not authorized in all the vineyards. This method is known to kill the endemic AM fungi (Cheng and Baumgartner 2004), and in the fumigated $\mathrm{P}$ deficient soils, vines are weaker due to the absence or the clear decrease of AM fungi (Menge et al. 1978). Even if soil fumigation does not suppressed $100 \%$ of the AMF inoculum in the soil (Menge 1982), it may decrease the diversity of AMF species to the extent that efficient colonizers of grapevine roots are eliminated from the AMF community (Cheng and Baumgartner 2004). It may also decrease the chances of 
grapevine roots encountering the most beneficial combination of AMF species. Therefore, if soils are fumigated before planting, then reintroducing AMF will likely greatly benefit plant establishment and growth.

\section{Conclusion}

Present-day vineyard practices place several constraints on the use of functions (Fig. 3) provided by mycorrhiza. The risk of large, costly, or irreversible changes is to be reduced or averted. Future (modern) agriculture should be based on the implementation of ecological management practices that deliberately maintain resilience of ecosystem services. This means integrating the development of vineyard management strategies that optimize the impact of beneficial microbes like mycorrhizal fungi on production. Furthermore, AMF vary in their ability to provide ecological services so that suitable tools have to be defined to fully assess their contribution. Molecular tools have considerably improved the possibility to identify and monitor mycorrhizal fungi in ecosystems, but a quick and reliable test for assessing their functionality is still lacking (Gianinazzi et al. 2010). For producers' expectations to be met, a novel industry encompassing soil/mycorrhiza analyses and advice to producers/managers is needed. Additional barriers to rationally exploiting beneficial soil microbes like mycorrhizal fungi as ecosystem services range from economical, technical, and cultural aspects to legislative questions. In spite of this, considerable progress has been made in the last decade for crop plants in general, but also for grapevine, towards the use of AMF.

\section{References}

Adesemoye AO, Torbert HA, Kloepper JW (2008) Enhanced plant nutrient use efficiency with PGPR and AMF in an integrated nutrient management system. Can J Microbiol 54:876-886. doi:10.1139/ W08-081

Al-Karaki GN (2006) Nursery inoculation of tomato with arbuscular mycorrhizal fungi and subsequent performance under irrigation with saline water. Sci Hortic-Amsterdam 109:1-7. doi:10.1016/j.scienta. 2006.02.019

Altieri MA (2002) Agroecology: the science of natural resource management for poor farmers in marginal environments. Agr Ecosyst Environ 93:1-24

Andersen CP, Markhart AH, Dixon RK, Sucoff EI (1988) Root hydraulic conductivity of vesicular-arbuscular mycorrhizal green ash seedlings. New Phytol 109:465-471

Andrade G, Mihara KL, Linderman RG, Bethlenfalvay GJ (1998) Soil aggregation status and rhizobacteria in the mycorrhizosphere. Plant Soil 202:89-96

Augé RM (2001) Water relations, drought and vesicular-arbuscular mycorrhizal symbiosis. Mycorrhiza 11:3-42
Avio L, Pellegrino E, Bonari E, Giovannetti M (2006) Functional diversity of arbuscular mycorrhizal fungal isolates in relation to extraradical mycelial networks. New Phytol 172:347-357. doi:10. 1111/j.1469-8137.2006.01839.x

Balestrini R, Magurno F, Walker C et al (2010) Cohorts of arbuscular mycorrhizal fungi (AMF) in Vitis vinifera, a typical Mediterranean fruit crop. Environ Microbiol Rep 2:594-604. doi:10.1111/j.17582229.2010.00160.x

Balvanera P, Pfisterer AB, Buchmann N et al (2006) Quantifying the evidence for biodiversity effects on ecosystem functioning and services. Ecol Lett 9:1146-1156. doi:10.1111/j.1461-0248.2006. 00963.x

Barea JM, Azcon-Aguilar C (1982) Production of plant growthregulating substances by the vesicular-arbuscular mycorrhizal fungus Glomus mosseae. Appl Environ Microbiol 43:810-813

Baumgartner K, Smith RF, Bettiga L (2005) Weed control and cover crop management affect mycorrhizal colonization of grapevine roots and arbuscular mycorrhizal fungal spore populations in a California vineyard. Mycorrhiza 15:111-119. doi:10.1007/s00572-004-0309-2

Baumgartner K, Fujiyoshi P, Smith R, Bettiga L (2010) Weed flora and dormant-season cover crops have no effects on arbuscular mycorrhizae of grapevine. Weed Res 50:456-466. doi:10.1111/j.13653180.2010.00793.x

Bavaresco L, Pezzutto S, Fornaroli A, Ferrari F (2003) Grapevine ironchlorosis occurrence and stilbene root concentration as affected by the rootstock and arbuscular mycorrhizal infection. Acta Horticult 603:401-410

Bavaresco L, Bertamini M, Iacono F (2006) Lime-induced chlorosis and physiological responses in grapevine (Vitis vinifera L. cv. Pinot blanc) leaves. Vitis 45:45-46

Bavaresco L, Gatti M, Zamboni M et al (2010) Role of artificial mycorrhization on iron uptake in calcareous soils, on stilbene root synthesis and in other physiological processes in grapevine. 33rd OIV world congress of vine and wine. 8th general assembly of the OIV- 20-25 june 2010 Tiblisi Georgia.

Baylis GTS (1975) The magnoloid mycorrhiza and mycotrophy in root systems derived from it. In: Sanders FE, Mosse B, Linker PE (eds) Endomycorrhiza. Academic, London, pp 373-389

Bedini S, Pellegrino E, Avio L et al (2009) Changes in soil aggregation and glomalin-related soil protein content as affected by the arbuscular mycorrhizal fungal species Glomus mosseae and Glomus intraradices. Soil Biol Biochem 41:1491-1496. doi:10. 1016/j.soilbio.2009.04.005

Belew D, Astatkie T, Mokashi MN et al (2010) Effects of salinity and mycorrhizal inoculation (Glomus fasiculatum) on growth responses of grape Rootstocks (Vitis spp.). South Afr J Enol Vitic 31:82-87

Besnard E, Chenu C, Robert M (2001) Influence of organic amendments on copper distribution among particle-size and density fractions in Champagne vineyard soils. Environ Pollut 112:329-337

Biricolti S, Ferrini F, Rinaldelli E et al (1997) VAM fungi and soil lime content influence rootstock growth and nutrient content. Am J Enol Vitic 48:93-99

Bokulich NA, Thorngate JH, Richardson PM, Mills DA (2014) Microbial biogeography of wine grapes is conditioned by cultivar, vintage, and climate. Proc Natl Acad Sci U S A 111:E139-E148. doi:10.1073/ pnas.1317377110/-/DCSupplemental

Bolan NS (1991) A critical review on the role of mycorrhizal fungi in the uptake of phosphorus by plants. Plant Soil 134:189-207

Bouamri R, Dalpe Y, Serrhini MN, Bennani A (2006) Arbuscular mycorrhizal fungi species associated with rhizosphere of Phoenix dactylifera L. in Morocco. Afr J Biotechnol 5:510-516

Brenot J, Quiquerez A, Petit C, Garcia J-P (2008) Erosion rates and sediment budgets in vineyards at 1-m resolution based on stock unearthing (Burgundy, France). Geomorphology 100:345-355. doi:10.1016/j.geomorph.2008.01.005 
Brun LA, Maillet J, Richarte J et al (1998) Relationships between extractable copper, soil properties and copper uptake by wild plants in vineyard soils. Environ Pollut 102:151-161. doi:10.1016/S02697491(98)00120-1

Buttrose M (1966) Use of carbohydrate reserves during growth from cutttings if grape vine. Aust J Biol Sci 19:247-256

Cameron DD, Neal AL, van Wees SCM, Ton J (2013) Mycorrhiza-induced resistance: more than the sum of its parts? Trends Plant Sci 18:539-545. doi:10.1016/j.tplants. 2013.06.004

Cangahuala-Inocente GC, Silva MF, Johnson J-M et al (2011) Arbuscular mycorrhizal symbiosis elicits proteome responses opposite of $\mathrm{P}$ starvation in $\mathrm{SO}_{4}$ grapevine rootstock upon root colonisation with two Glomus species. Mycorrhiza 21:473-493. doi:10.1007/s00572010-0352-0

Caravaca F, Alguacil MM, Azcón R, Roldán A (2006) Formation of stable aggregates in rhizosphere soil of Juniperus oxycedrus: effect of AM fungi and organic amendments. Appl Soil Ecol 33:30-38. doi:10.1016/j.apsoil.2005.09.001

Cavagnaro TR, Smith FA, Smith SE, Jakobsen I (2005) Functional diversity in arbuscular mycorrhizas: exploitation of soil patches with different phosphate enrichment differs among fungal species. Plant Cell Environ 28:642-650

Cetin ES, Guven Z, Ucar M (2014) The roles of arbuscular mycorrhizal fungi on some growth parameters and biochemical compounds on some Vitis rootstock. TABAD

Champagnol F (1978) Quelques problemes des vignobles des sables littoraux mediterraneens. Progres Agricole et Viticole

Chaves MM, Zarrouk O, Francisco R et al (2010) Deficit irrigation in Mediterranean environment. What lessons have we learnt from grapevine studies ?

Cheng X, Baumgartner K (2004) Arbuscular mycorrhizal fungi-mediated nitrogen transfer from vineyard cover crops to grapevines. Biol Fertil Soils 40:406-412. doi:10.1007/s00374-004-0797-4

Cheng X, Euliss A, Baumgartner K (2008) Nitrogen capture by grapevine roots and arbuscular mycorrhizal fungi from legume cover-crop residues under low rates of mineral fertilization. Biol Fertil Soils 44: 965-973. doi:10.1007/s00374-008-0281-7

Cho K, Toler H, Lee J et al (2006) Mycorrhizal symbiosis and response of sorghum plants to combined drought and salinity stresses. J Plant Physiol 163:517-528. doi:10.1016/j.jplph.2005.05.003

Choné X, Lavigne-Cruège V, van Leeuwen C et al (2006) Effet de la nutrition azotée de la vigne sur le potentiel aromatique du raisin: précurseurs d'arômes (s-conjugués à la cystéine), glutathion et composés dans le moût de Vitis vinifera $\mathrm{L}$. cv. Cabernet-sauvignon. J Int Sci Vigne Vin 40:1-6

Christensen, L. P. (2000) Raisin Production Manual. University of California, Agriculture \& Natural Resources, Communication Services

Christie P, Li X, Chen B (2004) Arbuscular mycorrhiza can depress translocation of zinc to shoots of host plants in soils moderately polluted with zinc. Plant Soil 261:209-217. doi:10.1023/B:PLSO. $0000035542.79345 .1 \mathrm{~b}$

Conradie WJ (1988) Effect of soil acidity on grapevine root growth and the role of roots as a source of nutrient reserves. In: van Zyl JL (ed) The grapevine root and its environment. Republic of So. Africa Dept. Agri. and Water Supply, Stellenbosch. So. Africa, pp 16-29

Conradie K (2004) Copper levels in South Africa nursery soils: possible effects in the propagation of grapevines. Wineland (South Africa)

Cook JA, Ward WR, Wicks AS (1983) Phosphorus deficiency in California vineyards. Calif Agric

Cornejo P, Pérez-Tienda J, Meier S et al (2013) Copper compartmentalization in spores as a survival strategy of arbuscular mycorrhizal fungi in Cu-polluted environments. Soil Biol Biochem 57:925928. doi:10.1016/j.soilbio.2012.10.031 de Andrade SA, da Silveira AP, Jorge RA, de Abreu MF (2008) Cadmium accumulation in sunflower plants influenced by arbuscular mycorrhiza. Int J Phytoremed 10:1-13

de Vries FT, Thébault E, Liiri M et al (2013) Soil food web properties explain ecosystem services across European land use systems. Proc Natl Acad Sci U S A 110:14296-14301. doi:10.1073/pnas. 1305198110

del Val C, Barea JM, Azcon-Aguilar C (1999) Assessing the tolerance to heavy metals of arbuscular mycorrhizal fungi isolated from sewage sludge-contaminated soils. Appl Soil Ecol 11:261-269

Deluisia A, Giandon P, Aichner M et al (1996) Copper pollution in Italian vineayrds soils. Commun Soil Sci Plant Anal 27:1537-1548

Donkó Á, Zanathy G, Èros-Honti Z et al (2014) Changes of mycorrhizal colonization along moist gradient in a vineyard of Eger (Hungary). Acta Univ Sap Agric Environ. doi:10.2478/ausae-2014-0008

Drouineau G (1942) Dosage rapide du calcaire actif du sol. Ann Agron $12: 441$

Eissenstat DM (1992) Costs and benefits of constructing roots of small diameter. J Plant Nutri 15:763-782

Farmer MJ, Li X, Feng G et al (2007) Molecular monitoring of fieldinoculated AMF to evaluate persistence in sweet potato crops in China. Appl Soil Ecol 35:599-609. doi:10.1016/j.apsoil.2006.09. 012

Fellbaum CR, Gachomo EW, Beesetty Y et al (2012) Carbon availability triggers fungal nitrogen uptake and transport in arbuscular mycorrhizal symbiosis. Proc Natl Acad Sci U S A 109:2666-2671. doi:10. 1073/pnas.1118650109

Feng G, Zhang FS, Li XL et al (2002) Improved tolerance of maize plants to salt stress by arbuscular mycorrhiza is related to higher accumulation of soluble sugars in roots. Mycorrhiza 12:185-190. doi:10. 1007/s00572-002-0170-0

Ferrol N, González-Guerrero M, Valderas A et al (2009) Survival strategies of arbuscular mycorrhizal fungi in Cu-polluted environments. Phytochem Rev 8:551-559. doi:10.1007/s11101-009-9133-9

Flores-Vélez LM, Ducaroir J, JAUNET AM, Robert M (1996) Study of the distribution of copper in an acid sandy vineyard soil by three different methods. Eur J Soil Sci 47:523-532. doi:10.1111/j.13652389.1996.tb01852.x

Fusconi A (2014) Regulation of root morphogenesis in arbuscular mycorrhizae: what role do fungal exudates, phosphate, sugars and hormones play in lateral root formation? Ann Bot-London 113:19-33. doi:10.1093/aob/mct258

Gachomo E, Allen JW, Pfeffer PE et al (2009) Germinating spores of Glomus intraradices can use internal and exogenous nitrogen sources for de novobiosynthesis of amino acids. New Phytol 184: 399-411. doi:10.1111/j.1469-8137.2009.02968.x

Gallou A, Mosquera HPL, Cranenbrouck S et al (2011) Mycorrhiza induced resistance in potato plantlets challenged by Phytophthora infestans. Physiol Mol Plant P 76:20-26. doi:10.1016/j.pmpp. 2011.06.005

García IV, Mendoza RE (2007) Arbuscular mycorrhizal fungi and plant symbiosis in a saline-sodic soil. Mycorrhiza 17:167-174. doi:10. 1007/s00572-006-0088-z

Gärtel W (1965) Über den diagnostischen Wert des Blattanalyse bei der Identifizierung von Ernährungsstörungen bei Reben. Vignes Vins 138:25-29

Gianinazzi S, Gollotte A, Binet MN et al (2010) Agroecology: the key role of arbuscular mycorrhizas in ecosystem services. Mycorrhiza 20:519-530. doi:10.1007/s00572-010-0333-3

Gilbert JA, van der Lelie D, Zarraonaindia I (2014) Microbial terroir for wine grapes. Proc Natl Acad Sci U S A 111:5-6. doi:10.1073/pnas. 1320471110

Giri B, Mukerji KG (2004) Mycorrhizal inoculant alleviates salt stress in Sesbania aegyptiaca and Sesbania grandiflora under field conditions: evidence for reduced sodium and improved magnesium uptake. Mycorrhiza 14:307-312. doi:10.1007/s00572-003-0274-1 
Giri B, Kapoor R, Mukerji KG (2003) Influence of arbuscular mycorrhizal fungi and salinity on growth, biomass, and mineral nutrition of Acacia auriculiformis. Biol Fertil Soils 38:170-175. doi:10.1007/ s00374-003-0636-z

Giri B, Kapoor R, Mukerji KG (2007) Improved tolerance of Acacia nilotica to salt stress by arbuscular mycorrhiza, Glomus fasciculatum may be partly related to elevated $\mathrm{K} / \mathrm{Na}$ ratios in root and shoot tissues. Microb Ecol 54:753-760. doi:10.1007/s00248007-9239-9

Gogoi P, Singh RK (2011) Differential effect of some arbuscular mycorrhizal fungi on growth of Piper longum L. (Piperaceae). Indian J Sci Tech 4:119-125

Göhre V, Paszkowski U (2006) Contribution of the arbuscular mycorrhizal symbiosis to heavy metal phytoremediation. Planta 223:11151122. doi:10.1007/s00425-006-0225-0

González-Chávez MC, Carrillo-González R, Wright SF, Nichols KA (2004) The role of glomalin, a protein produced by arbuscular mycorrhizal fungi, in sequestering potentially toxic elements. Environ Pollut 130:317-323. doi:10.1016/j.envpol.2004.01.004

Gunatilake HM (2000) Estimation of on-site cost of soil erosion: a comparison of replacement and productivity change methods. J Soil Water Conserv 55:197-204

Guo W, Zhao R, Zhao W et al (2013) Effects of arbuscular mycorrhizal fungi on maize (Zea mays L.) and sorghum (Sorghum bicolor L. Moench) grown in rare earth elements of mine tailings. Appl Soil Ecol 72:85-92. doi:10.1016/j.apsoil.2013.06.001

Gustafson DJ, Casper BB (2005) Differential host plant performance as a function of soil arbuscular mycorrhizal fungal communities: experimentally manipulating co-occurring Glomus species. Plant Ecol 183:257-263. doi:10.1007/s11258-005-9037-8

Hao Z, Fayolle L, van Tuinen D et al (2012) Local and systemic mycorrhiza-induced protection against the ectoparasitic nematode Xiphinema index involves priming of defence gene responses in grapevine. J Exp Bot 63:3657-3672. doi:10.1093/jxb/ers046

Harrison MJ (1999) Molecular and cellular aspects of the arbuscular mycorrhizal symbiosis. Annu Rev Plant Physiol Plant Mol Biol 50:361-389. doi:10.1146/annurev.arplant.50.1.361

Hart MM, Reader R (2002a) Does percent root length colonization and soil hyphal length reflect the extent of colonization for all AMF? Mycorrhiza 12:297-301. doi:10.1007/s00572-002-0186-5

Hart MM, Reader RJ (2002b) Taxonomic basis for variation in the colonization strategy of arbuscular mycorrhizal fungi. New Phytol 153: 335-344

Hasegawa K, Matsushita M, Kitajima A (2000) Effect of trunk strapping time on fruit set and quality in Persimmon cv. Matsumotowase fuyu, II International Persimmon

Hawkins H-J, Johansen A, George E (2000) Uptake and transport of organic and inorganic nitrogen by arbuscular mycorrhizal fungi. Plant Soil 226:275-285

Hayek S, Grosch R, Gianinazzi-Pearson V, Franken P (2012) Bioprotection and alternative fertilisation of petunia using mycorrhiza in a soilless production system. Agron Sustain Dev. doi:10. 1007/s13593-012-0083-z

Hector A, Bagchi R (2007) Biodiversity and ecosystem multifunctionality. Nature 448:188-190. doi:10.1038/nature05947

Hodge A, Fitter AH (2010) Substantial nitrogen acquisition by arbuscular mycorrhizal fungi from organic material has implications for $\mathrm{N}$ cycling. Proc Natl Acad Sci U S A 107:13754-13759. doi:10.1073/ pnas.1005874107/-/DCSupplemental

Holland TC, Bowen P, Bogdanoff C, Hart MM (2014) How distinct are arbuscular mycorrhizal fungal communities associating with grapevines? Biol Fertil Soils 50:667-674

IPCC (2014) Climate change 2014: synthesis report. Contribution of working groups I, II and III to the fifth assessment report of the intergovernmental panel on climate change [Core Writing Team,
R.K. Pachauri and L.A. Meyer (eds.)]. IPCC, Geneva, Switzerland, $151 \mathrm{pp}$

Jackson RS (2014) Wine science: principle and applications. Science, Elsevier

Jang JC, Sheen J (1997) Sugar sensing in higher plants. Trends Plant Sci 2:208-214

Jansa J, Smith FA, Smith SE (2008) Are there benefits of simultaneous root colonization by different arbuscular mycorrhizal fungi? New Phytol 177:779-789. doi:10.1111/j.1469-8137.2007.02294.x

Javot H, Penmetsa RV, Terzaghi N et al (2007) A Medicago truncatula phosphate transporter indispensable for the arbuscular mycorrhizal symbiosis. Proc Natl Acad Sci U S A 104:1720-1725. doi:10.1073/ pnas.0608136104

Jeffries P, Gianinazzi S, Perotto S et al (2003) The contribution of arbuscular mycorrhizal fungi in sustainable maintenance of plant health and soil fertility. Biol Fertil Soils 37:1-16. doi:10.1007/ s00374-002-0546-5

Johansen A, Jakobsen I, Jensen ES (1992) Hyphal transport of ${ }^{15} \mathrm{~N}-\mathrm{la}-$ belled nitrogen by a vesicular - arbuscular mycorrhizal fungus and its effect on depletion of inorganic soil N. New Phytol 122:281-288

Johansen A, Finlay RD, Olsson PA (1996) Nitrogen metabolism of external hyphae of the arbuscular mycorrhizal fungus Glomus intraradices. New Phytol 133:705-712

Joner EJ, Briones R, Leyval C (2000) Metal-binding capacity of arbuscular mycorrhizal mycelium. Plant Soil 226:227-234

Jones GV, Davis RE (2000) Climate influences on grapevine phenology, grape composition, and wine production and quality for Bordeaux, France. Am J Enol Viticult 51:249-261

Jordan N, Zhang J, Huerd S (2000) Arbuscular-mycorrhizal fungi: potential roles in weed management. Weed Res 40:397-410

Jung SC, Garcia-Andrade J, Verhage A, et al (2012) Arbuscular mycorrhiza induce systemic resistance against gray mold (Botrytis cinerea) in tomato through priming of JA-dependent defense responses. In: Schmitt A, Mauch-Mani B, Pozo MJ, et al (eds) Proceedings of the IOBC/WPRS Working group. Induced resistance in plants against insects and diseases. Granada, pp 139-144

Karagiannidis N, Nikolaou N (1999) Arbuscular mycorrhizal root infection as an important factor of grapevine nutrition status Multivariate analysis application for evaluation and characterization of the soil and leaf parameters. Agrochimica 43:151-165

Karagiannidis N, Nikolaou N, Ipsilantis I, Zioziou E (2007) Effects of different $\mathrm{N}$ fertilizers on the activity of Glomus mosseae and on grapevine nutrition and berry composition. Mycorrhiza 18:43-50. doi:10.1007/s00572-007-0153-2

Khade SW, Alok A (2009) Arbuscular mycorrhizal association in plants growing on metal-contaminated and noncontaminated soils adjoining Kanpur Tanneries, Uttar Pradesh, India. Water Air Soil Pollut 202:45-56. doi:10.1007/s11270-008-9957-8

Khalil HA (2013) Influence of Vesicular-arbuscula Mycorrhizal Fungi (Glomus spp.) on the Response of Grapevines Rootstocks to Salt Stress. Asian Journal of Crop Science

Khan AG (2006) Mycorrhizoremediation - an enhanced form of phytoremediation. J Zhejiang Univ (Sci B) 7:503-514

Khaosaad T, García-Garrido JM, Steinkellner S, Vierheilig H (2007) Take-all disease is systemically reduced in roots of mycorrhizal barley plants. Soil Biol Biochem 39:727-734. doi:10.1016/j. soilbio.2006.09.014

Kohler J, Hernández JA, Caravaca F, Roldán A (2008) Plant-growthpromoting rhizobacteria and arbuscular mycorrhizal fungi modify alleviation biochemical mechanisms in water-stressed plants. Funct Plant Biol 35:141-151. doi:10.1071/FP07218

Koide R, Dickie I (2002) Effect of mycorrhizal fungi on plant populations. In: Smith S, Smith FA (eds) Diversity and integration in mycorrhizas. Springer, Netherlands, pp 307-317

Komárek M, Čadková E, Chrastný V et al (2010) Contamination of vineyard soils with fungicides: a review of environmental and 
toxicological aspects. Environ Int 36:138-151. doi:10.1016/j. envint.2009.10.005

Kothari SK, Marschner H, Römheld V (1991) Effect of a vesiculararbuscular mycorrhizal fungus and rhizosphere microorganisms on manganese reduction in the rhizosphere and manganese concentrations in maize (Zea mays L.). New Phytol 117:649-655

Krishna H, Singh SK, Sharma RR, Khawale RN (2005) Biochemical changes in micropropagated grape (Vitis vinifera L.) plantlets due to arbuscular-mycorrhizal fungi (AMF) inoculation during ex vitro acclimatization. Sci Hortic-Amsterdam 106:554-567

Lal R (1987) Effects of soil erosion on crop productivity. CRC Crit Rev Plant Sci 5:303-367

Lal R (2009) Soil degradation as a reason for inadequate human nutrition. Food Secure 1:45-57

Lanfranco L (2002) Differential expression of a metallothionein gene during the presymbiotic versus the symbiotic phase of an arbuscular mycorrhizal fungus. Plant Physiol 130:58-67. doi:10.1104/pp. 003525

Le Bissonnais Y, Montier C, Jamague M et al (2001) Mapping erosion risk for cultivated soil in France. Catena 46:207-220

Li ZT, Dhekney SA, Gray DJ (2010) PR-1 gene family of grapevine: a uniquely duplicated PR-1 gene from a Vitis interspecific hybrid confers high level resistance to bacterial disease in transgenic tobacco. Plant Cell Rep 30:1-11. doi:10.1007/s00299-010-0934-5

Lindermann RG, Davis EA (2001) Comparative response of selected grapevine rootstocks and cultivars to inoculation with different mycorrhizal fungi. Am J Enol Vitic 52:8-11

Loeppert RH, Wei LC, Ocuwpaugh R (1994) Soil factors influencing the mobilization in calcareous soils, Biochemistry of metal micronutrients in the rhizosphere. CRC Press Inc, Boca Raton, FL, USA, pp 343-360

Lopez-Millan AF, Sagardoy R, Solanas M et al (2009) Cadmium toxicity in tomato (Lycopersicon esculentum) plants grown in hydroponics. Environ Exp Bot 65:376-385. doi:10.1016/j.envexpbot.2008.11. 010

Loreti E (2001) Why and how do plant cells sense sugars? Ann BotLondon 88:803-812. doi:10.1006/anbo.2001.1526

Lumini E, Orgiazzi A, Borriello R et al (2010) Disclosing arbuscular mycorrhizal fungal biodiversity in soil through a land-use gradient using a pyrosequencing approach. Environ Microbiol 12:21652179. doi:10.1111/j.1462-2920.2009.02099.x

Maas EV, Hoffman GJ (1977) Crop salt tolerance current assessment. J Irrig Drain 103:115-134

Magalhães MJ, Sequeira EM, Lucas MD (1985) Copper and zinc in vineyards of Central Portugal. Water Air Soil Pollut 26:1-17

Martínez-Casanovas JA, Ramos MC (2006) The cost of soil erosion in vineyard fields in the Penedès-Anoia Region (NE Spain). Catena 68:194-199. doi:10.1016/j.catena.2006.04.007

Marzluf GA (1997) Genetic regulation of nitrogen metabolism in the fungi. Microbiol Mol Biol Rev 61:17-32

Meier S, Azcón R, Cartes P et al (2011) Alleviation of $\mathrm{Cu}$ toxicity in Oenothera picensis by copper-adapted arbuscular mycorrhizal fungi and treated agro waste residue. Appl Soil Ecol 48:117-124. doi:10. 1016/j.apsoil.2011.04.005

Menge JA (1982) Effect of soil fumigants and fungicides on vesiculararbuscular fungi. Phytopathol 72(8):1125-1132

Menge JA, Munnecke DE, Johnson ELV, Carnes DW (1978) Dosage response of the vesicular-arbuscular mycorrhizal fungi Glomus fasciculatus and G. constrictus to methyl bromide. Phytopathol 68:1368-1372

Menge JA, Raski D, Lider LA (1983) Interactions between mycorrhizal fungi, soil fumigation, and growth of grapes in California. Am J Enol Vitic 34:117-121

Miotto A, Ceretta CA, Brunetto G et al (2013) Copper uptake, accumulation and physiological changes in adult grapevines in response to excess copper in soil. Plant Soil 374:593-610. doi:10.1007/s11104013-1886-7

Mirlean N, Roisenberg A, Chies JO (2007) Metal contamination of vineyard soils in wet subtropics (southern Brazil). Environ Pollut 149: 10-17. doi:10.1016/j.envpol.2006.12.024

Mortimer PE, Archer E, Valentine AJ (2005) Mycorrhizal C costs and nutritional benefits in developing grapevines. Mycorrhiza 15:159 165. doi: $10.1007 / \mathrm{s} 00572-004-0317-2$

Motosugi H, Yamamoto Y, Naruo T (2002) Comparison of the growth and leaf mineral concentrations between three grapevine rootstocks and their corresponding tetraploids inoculated with an arbuscular mycorrhizal fungus Gigaspora margarita. Vitis 41:21-25

Munkvold L, Kjøller R, Vestberg M et al (2004) High functional diversity within species of arbuscular mycorrhizal fungi. New Phytol 164: 357-364. doi:10.1111/j.1469-8137.2004.01169.x

Neumann E, George E (2004) Colonisation with the arbuscular mycorrhizal fungus Glomus mosseae (Nicol. \& Gerd.) enhanced phosphorus uptake from dry soil in Sorghum bicolor (L.). Plant Soil 261: 245-255

Nikolaou N, Karagiannidis N, Koundouras S, Fysarakis I (2002) Effects of different $\mathrm{P}$ sources in soil on increasing growth and mineral uptake of mycorrhizal Vitis vinifera L. (cv. Victoria) vines. J Int Sci Vigne Vin 36:195-204

Ninkov J, Paprić Đ, Sekulić P et al (2012) Copper content of vineyard soils at Sremski Karlovci (Vojvodina Province, Serbia) as affected by the use of copper-based fungicides. Int J Environ An Chem 92: 592-600. doi:10.1080/03067310903428743

Nogales A, Luque J, Estaún V et al (2009) Differential growth of mycorrhizal field-inoculated grapevine rootstocks in two replant soils. Am J Enol Vitic 60:484-489

Nye PH, Tinker PB (1977) Solute movement in the soil-root system: studies in ecology. Blackwell Scientific Publications, Oxford

Oehl F, Sieverding E, Ineichen K et al (2005) Community structure of arbuscular mycorrhizal fungi at different soil depths in extensively and intensively managed agroecosystems. New Phytol 165:273283. doi:10.1111/j.1469-8137.2004.01235.x

Parniske M (2008) Arbuscular mycorrhiza: the mother of plant root endosymbioses. Nat Rev Microbiol 6:763-775. doi:10.1038/ nrmicro1987

Petgen M, Schropp A, George E, Römheld V (1998) Einfluss unterschieblicher Inokulationstiefen mit dem arbuskulèaren MykorrhizapiltzGlomus mosseaeauf die Mykorrhizierung bei Reben (Vitissp.) in Wurzelbeobachtungskäten. Vitis 37:99-105

Petit E, Gubler WD (2006) Influence of Glomus intraradices on black foot disease caused by Cylindrocarpon Macrodidymumon Vitis Rupestris under controlled conditions. Plant Dis 90:1481-1484. doi:10.1094/PD-90-1481

Peyret-Guzzon M, Stockinger H, Bouffaud ML, et al (2015) Arbuscular mycorrhizal fungal communities and Rhizophagus irregularis populations shift in response to short-term ploughing and fertilisation in a buffer strip. Mycorrhiza 1-14. doi: 10.1007/s00572-015-0644-5

Pimentel D (1995) Amounts of pesticides reaching target pests: environmental impacts and ethics. J Agri Environ Ethic 81:17-29

Pineda A, Zheng S-J, van Loon JJA et al (2010) Helping plants to deal with insects: the role of beneficial soil-borne microbes. Trends Plant Sci 15:507-514. doi:10.1016/j.tplants.2010.05.007

Pinkerton JN, Forge TA, Ivors KL, Ingham RE (1999) Plant-parasitic nematodes associated with grapevines, Vitis vinifera, in Oregon vineyards. J Nematol 31:624-634

Pinkerton JN, Schreiner RP, Ivors KL, Vasconcelos MC (2004) Effects of Mesocriconema xenoplax on Vitis vinifera and associated mycorrhizal fungi. J Nematol 36:193-201

Porras-Soriano A, Soriano-Martin ML, Porras-Piedra A, Azcón R (2009) Arbuscular mycorrhizal fungi increased growth, nutrient uptake and tolerance to salinity in olive trees under nursery conditions. J Plant Physiol 166:3538-3545 
Pozo MJ, Azcon-Aguilar C (2007) Unraveling mycorrhiza-induced resistance. Curr Opin Plant Biol 10:393-398. doi:10.1016/j.pbi.2007.05. 004

Pozo MJ, Azcon-Aguilar C, Dumas-Gaudot E, Barea JM (1999) $\beta-1,3-$ Glucanase activities in tomato roots inoculated with arbuscular mycorrhizal fungi and/or Phytophthora parasitica and their possible involvement in bioprotection. Plant Sci 141:149-157

Querejeta JI, Allen MF, Caravaca F, Roldán A (2006) Differential modulation of host plant $\delta{ }^{13} \mathrm{C}$ and $\delta{ }^{18} \mathrm{O}$ by native and nonnative arbuscular mycorrhizal fungi in a semiarid environment. New Phytol 169:379-387. doi:10.1111/j.1469-8137.2005.01599.x

Rabie GH (2005) Influence of arbuscular mycorrhizal fungi and kinetin on the response of mungbean plants to irrigation with seawater. Mycorrhiza 15:225-230. doi:10.1007/s00572-004-0345-y

Radic T, Hancevic K, Likar M et al (2012) Neighbouring weeds influence the formation of arbuscular mycorrhiza in grapevine. Symbiosis 56 : $111-120$

Radin JW, Eidenbock MP (1984) Hydraulic conductance as a factor limiting leaf expansion of phosphorus-deficient cotton plants. Plant Physiol 75:372-377

Radin JW, Matthews MA (2004) Water transport properties of cortical cells in roots of nitrogen-deficient and phosphorus-deficient cotton seedlings. Plant Physiol 89:264-2687

Ramos MC, Martínez-Casanovas JA (2004) Nutrient losses from a vineyard soil in Northeastern Spain caused by an extraordinary rainfall event. Catena 55:79-90. doi:10.1016/S0341-8162(03)00074-2

Read D (1992) The mycorrhizal mycelium. In: Allen M(ed) Mycorrhizal functioning: an integrative plant-fungal process. Springer Science \& Business Media, pp 102-133

Redecker D (2000) Glomalean fungi from the ordovician. Science 289: 1920-1921. doi:10.1126/science.289.5486.1920

Redecker D, Schüssler A, Stockinger H, Stürmer SL, Morton JB, Walker C (2013) An evidence-based consensus for the classification of arbuscular mycorrhizal fungi (Glomeromycota). Mycorrhiza 23: 515-531. doi:10.1007/s00572-013-0486-y

Reinbott TM, Blevins DG (1999) Phosphorus nutritional effects on root hydraulic conductance, xylem water flow and flux of magnesium and calcium in squash plants. Plant Soil 209:263-273

Reynolds AG (2010) Managing wine quality: viticulture and wine quality. Science, Elsevier

Richard D (1983) The grape root system. Horticult Rev 5:127-168

Ridgway HJ, Kandula J, Stewart A (2006) Optimising the medium for producing arbuscular mycorrhizal spores and the effect of inoculation on grapevine growth. New Zea Plant Protec 59:338-342

Rillig MC, Mummey DL (2006) Mycorrhizas and soil structure. New Phytol 171:41-53. doi:10.1111/j.1469-8137.2006.01750.x

Rillig MC, Wright SF, Eviner VT (2002) The role of arbuscular mycorrhizal fungi and glomalin in soil aggregation: comparing effects of five plant species. Plant Soil 238:325-333

Rillig MC, Aguilar-Trigueros CA, Bergmann J et al (2014) Plant root and mycorrhizal fungal traits for understanding soil aggregation. New Phytol 205(4):1385-1388. doi:10.1111/nph.13045

Rivera-Becerril F, Calantzis C, Turnau K et al (2002) Cadmium accumulation and buffering of cadmium-induced stress by arbuscular in three Pisum sativum L. genotypes. J Exp Bot 53:1177-1185

Ruiz-Lozano JM (2003) Arbuscular mycorrhizal symbiosis and alleviation of osmotic stress. New perspectives for molecular studies. Mycorrhiza 13:309-317. doi:10.1007/s00572-003-0237-6

Sannazzaro AI, Ruiz OA, Albertó EO, Menéndez AB (2006) Alleviation of salt stress in Lotus glaber by Glomus intraradices. Plant Soil 285: 279-287. doi:10.1007/s11104-006-9015-5

Schreiner RP (2005a) Spatial and temporal variation of roots, arbuscular mycorrhizal fungi, and plant and soil nutrients in a mature pinot noir (Vitis vinifera 1.) vineyard in Oregon, USA. Plant Soil 276:219-234. doi:10.1007/s11104-005-4895-0
Schreiner RP (2005b) Mycorrhizae and mineral acquisition in grapevines. In: Christensen, L. P., Smart D (eds) Proceedings of the Soil Environment and Vine Mineral Nutrition Symposium. JP Christensen and DR Smart (Eds.). pp 49-60

Schreiner RP, Mihara KL (2009) The diversity of arbuscular mycorrhizal fungi amplified from grapevine roots (Vitis vinifera L.) in Oregon vineyards is seasonally stable and influenced by soil and vine age. Mycologia 101:599-611. doi:10.3852/08-169

Schreiner RP, Tarara JM, Smithyman RP (2007) Deficit irrigation promotes arbuscular colonization of fine roots by mycorrhizal fungi in grapevines (Vitis vinifera L.) in an arid climate. Mycorrhiza 17:551562. doi:10.1007/s00572-007-0128-3

Schubert A, Cravero MC (1985) Occurrence and infectivity of vesiculararbuscular mycorrhizal fungi in north-western Italy vineyards. Vitis 24:129-138

Schüßler A, Schwarzott D, Walker C (2001) A new fungal phylum, the Glomeromycota: phylogeny and evolution. Mycol Res 105:14131421. doi:10.1017/S0953756201005196

Setati ME, Jacobson D, Andong U-C, Bauer F (2012) The vineyard yeast microbiome, a mixed model microbial map. PLoS One 7, e52609. doi:10.1371/journal.pone.0052609.s005

Shannon MC, Grieve CM (1998) Tolerance of vegetable crops to salinity. Sci Horticult-Amsterdam 78:5-38. doi:10.1016/S0304-4238(98) 00189-7

Sharma D, Kapoor R, Bhatnagar AK (2009) Differential growth response of Curculigo orchioides to native arbuscular mycorrhizal fungal (AMF) communities varying in number and fungal components. Eur J Soil Biol 45:328-333. doi:10.1016/j.ejsobi.2009.04.005

Skinner PW, Matthews MA (1989) Reproductive development in grape (Vitis vinifera L.) under phosphorus-limited conditions. Sci Horticult-Amsterdam 38:49-60. doi:10.1016/0304-4238(89) 90019-8

Smart D, Schwass E, Lakso A, Morano L (2006) Grapevine rooting patterns: a comprehensive analysis and review. Am J Enol Vitic $57: 89-104$

Smith SE (2003) Mycorrhizal fungi can dominate phosphate supply to plants irrespective of growth responses. Plant Physiol 133:16-20. doi:10.1104/pp. 103.024380

Smith SE, Read DJ (2008) Mycorrhizal Symbiosis, Third Edition, 3rd edn. Academic Press

Smith SE, Facelli E, Pope S, Andrew Smith F (2010) Plant performance in stressful environments: interpreting new and established knowledge of the roles of arbuscular mycorrhizas. Plant Soil 326:3-20. doi:10.1007/s11104-009-9981-5

Smith SE, Jakobsen I, Grønlund M, Smith FA (2011) Roles of arbuscular mycorrhizas in plant phosphorus nutrition: interactions between pathways of phosphorus uptake in arbuscular mycorrhizal roots have important implications for understanding and manipulating plant phosphorus acquisition. Plant Physiol 156:1050-1057. doi: $10.1104 /$ pp. 111.174581

Southey JM, Archer E (2015) The effect of rootstock cultivar on grapevine root distribution and density. In: van Zyl JL (ed) The Grapevine root and its environment, Technical comm. Pretoria, pp 57-73

Stockinger H, Peyret-Guzzon M, Koegel S et al (2014) The largest subunit of RNA polymerase II as a new marker gene to study assemblages of arbuscular mycorrhizal fungi in the field. PLoS One 9, e107783. doi:10.1371/journal.pone.0107783.s013

Stockinger H, Walker C, Schüssler A (2009) Glomus intraradices DAOM197198, a model fungus in arbuscular mycorrhiza research, is not Glomus intraradices. New Phytol 183: 1176-1187

Sylvia DM, Williams SE (1992) Vesicular-arbuscular mycorrhizae and environmental stress. ASA special Publication 54:101-124

Tagliavini M, Rombolà AD (2001) Iron deficiency and chlorosis in orchard and vineyard ecosystems. Eur J Agron 15:71-92. doi:10. 1016/S1161-0301(01)00125-3 
Toussaint J-P, St-Arnaud M, Charest C (2004) Nitrogen transfer and assimilation between the arbuscular mycorrhizal fungus Glomus intraradices Schenck \& Smith and Ri T-DNA roots of Daucus carota L. in an in vitro compartmented system. Can J Microbiol 50:251-260. doi:10.1139/w04-009

Tulloch HW, Harris WB (1970) Fertilizer responses with non-irrigated Shiraz grapevines, 1944-1966. Crop and Pasture Science 21:243252. doi: 10.1071/AR9700243

Valentine AJ, Mortimer PE, Lintnaar M, Borgo R (2006) Drought responses of arbuscular mycorrhizal grapevines. Symbiosis 41:127133

Valero E, Cambon B, Schuller D et al (2007) Biodiversity of Saccharomyces yeast strains from grape berries of wine-producing areas using starter commercial yeasts. FEMS Yeast Res 7:317-329. doi:10.1111/j.1567-1364.2006.00161.x

van der Heijden MGA, Klironomos JN, Ursic M et al (1998) Mycorrhizal fungal diversity determines plant biodiversity, ecosystem variability and productivity. Nature 396:69-72

van Rooyen M, Valentine A, Archer E (2004) Arbuscular mycorrhizal colonisation modifies the water relations of young transplanted grapevines (Vitis). South Afr J Enol Vitic 25:37-42

Verbruggen E, Kiers TE (2010) Evolutionary ecology of mycorrhizal functional diversity in agricultural systems. Evol Appl 3:547-560. doi:10.1111/j.1752-4571.2010.00145.x

Viets F (1972) Water deficits and nutrient availability. In: Kozlowski T (ed) Water deficits and plant growth. Academic Press Ltd, New York, pp 217-239

Wagg C, Bender SF, Widmer F, van der Heijden MGA (2014) Soil biodiversity and soil community composition determine ecosystem multifunctionality. Proc Natl Acad Sci U S A 111:5266-5270. doi: 10.1073/pnas.1320054111

Walker GR, Zhang L, Ellis TW et al (2002) Estimating impacts of changed land use on recharge: review of modelling and other approaches appropriate for management of dryland salinity. Hydrogeol J 10:68-90. doi:10.1007/s10040-001-0181-5

Walker RR, Blackmore DH, Clingeleffer PR (2010) Impact of rootstock on yield and ion concentrations in petioles, juice and wine of Shiraz and Chardonnay in different viticultural environments with different irrigation water salinity. Aust J Grape Wine Res 16:243-257. doi:10. 1111/j.1755-0238.2009.00081.x

Wang B, Qiu YL (2006) Phylogenetic distribution and evolution of mycorrhizas in land plants. Mycorrhiza 16:299-363. doi:10.1007/ s00572-005-0033-6

Wang W, Xie Z-P, Staehelin C (2014) Functional analysis of chimeric LysM domain receptors mediating Nod factor-induced defense signaling in Arabidopsis thaliana and chitin-induced nodulation signaling in Lotus japonicus. The Plant Journal. doi:10.1111/tpj.12450

Waschkies C, Schropp A, Marschner H (1994) Relations between grapevine replant disease and root colonization of grapevine (Vitis sp.) by fluorescent pseudomonads and endomycorrhizal fungi. Plant Soil 162:219-227

Webb LB, Whetton PH, Barlow EWR (2007) Modelled impact of future climate change on the phenology of winegrapes in Australia. Aust $\mathrm{J}$ Grape Wine Res 13:165-175. doi:10.1111/j.1755-0238.2007. tb00247.x

Wermelinger B, Baumgärtner J, Gutierrez AP (1991) A demographic model of assimilation and allocation of carbon and nitrogen in grapevines. Ecol Model 53:1-26

Wightwick AM, Mollah MR, Partington DL, Allinson G (2008) Copper fungicide residues in Australian vineyard soils. J Agric Food Chem 56:2457-2464. doi:10.1021/jf0727950

Wilson GWT, Rice CW, Rillig MC et al (2009) Soil aggregation and carbon sequestration are tightly correlated with the abundance of arbuscular mycorrhizal fungi: results from long-term field experiments. Ecol Lett 12:452-461. doi:10.1111/j.1461-0248.2009. 01303. $\mathrm{x}$

Wright DP, Scholes JD, Read DJ (1998) Effects of VA mycorrhizal colonization on photosynthesis and biomass production of Trifolium repens L. Plant Cell Environ 21:209-216. doi:10.1046/j.13653040.1998.00280.x

Yano-Melo AM, Saggin OJ Jr, Costa Maia L (2003) Tolerance of mycorrhized banana (Musa sp. cv. Pacovan) plantlets to saline stress. Agr Ecosyst Environ 95:343-348 